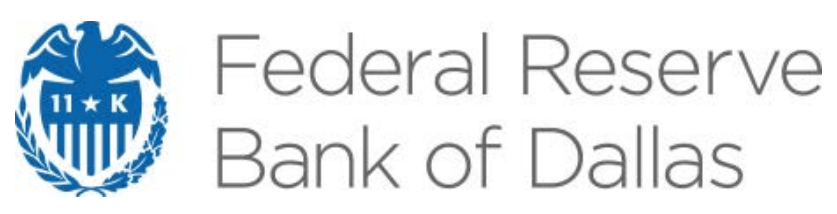

\title{
Capital Controls as Macro-prudential Policy in a Large Open Economy
}

J. Scott Davis and Michael B. Devereux

\section{Globalization Institute Working Paper 358}

Research Department

https://doi.org/10.24149/gwp358

Working papers from the Federal Reserve Bank of Dallas are preliminary drafts circulated for professional comment. The views in this paper are those of the authors and do not necessarily reflect the views of the Federal Reserve Bank of Dallas or the Federal Reserve System. Any errors or omissions are the responsibility of the authors. 


\title{
Capital Controls as Macro-prudential Policy in a Large Open Economy*
}

\author{
J. Scott Davis ${ }^{\dagger}$ and Michael B. Devereux ${ }^{\ddagger}$
}

March 27, 2019

\begin{abstract}
The literature on optimal capital controls for macro-prudential policy has focused on capital controls in a small open economy. This ignores the spillover effects to the rest of the world. This paper re-examines the case for capital controls in a large open economy, where domestic financial constraints may bind following a large negative shock. There is a tension between the desire to tax inflows to manipulate the terms of trade and tax outflows for macro-prudential purposes. Non-cooperative capital controls are ineffective as macro-prudential policy. Cooperative policy will ignore terms-of-trade manipulation and thus cooperative capital controls yield more effective macro-prudential policy.
\end{abstract}

JEL Codes: F40

Keywords: Capital controls, large open economy, terms-of-trade, macroprudential, crisis management

\footnotetext{
* The views in this paper are those of the authors and do not necessarily represent the views of the Federal Reserve Bank of Dallas or the Federal Reserve System. We thank participants in the 3rd International Macro Conference in Keio University, March 2018, and the FRB Dallas - University of Houston - Bank of Mexico Conference on International Economics, October 2018. In addition, we thank Martin Bodenstein, Guido Lorenzoni, Mark Aguiar, and Emmanuel Fahri for comments. Devereux gratefully acknowledges financial support from the Social Science and Humanities Research Council of Canada. ${ }^{\dagger}$ Corresponding author: J. Scott Davis, Federal Reserve Bank of Dallas, 2200 N. Pearl St., Dallas, TX 75201, USA, scott.davis@dal.frb.org.

${ }^{\ddagger}$ Michael B. Devereux, University of British Columbia, michael.devereux@ubc.ca.
} 


\section{Introduction}

The use of capital controls has a long history in international economic policy (see e.g. Edwards (1999) and Magud et al. (2018) for empirical surveys), but the recent experience of financial crises has led to a substantial reevaluation of the benefits of controls. ${ }^{1}$ A growing theoretical literature has argued for the use of capital controls as second best policy to correct inefficiencies in international financial markets. ${ }^{2}$

One common example often cited is the presence of pecuniary externalities associated with financial constraints facing borrowers (see e.g. Lorenzoni (2008)). In an open economy, exogenous changes in capital inflows from abroad can lead to changes in asset prices and the price of collateral and heighten this pecuniary externality. In open economy models, some papers take a positive approach and model the way that this pecuniary externality can replicate the behavior of financial crises in many emerging market economies (see e.g. Mendoza (2010)). Others take a normative approach and show that by taxing capital flows, governments may be able to correct these externalities, which otherwise would lead to inefficient levels of borrowing. Policy can potentially be employed ex-post to ease a crisis already occurring (crisis management) or ex-ante to increase financial stability (crisis prevention) (see e.g. Jeanne and Korinek (2010), Bianchi (2011), Benigno et al. (2013), Korinek and Sandri (2016), Korinek (2018), Bianchi and Mendoza (2018)). ${ }^{3}$

Most of the literature analyzing the efficacy of capital flow controls focuses on the case of a small economy which takes the availability of capital from the outside world as given. But this perspective ignores a number of important features of international financial markets which may be important in the evaluation of optimal capital controls. First, for large countries, the patterns of borrowing and lending undertaken in response to macro shocks are likely to have spillover impacts on the rest of the world. Unlike a small economy, capital controls policy in

\footnotetext{
${ }^{1}$ In particular, the change in the position of the IMF on use of capital controls after the financial crisis has been well documented (see e.g. International Monetary Fund (2012))

${ }^{2}$ See Ma and Rebucci (2019) for a recent survey.

${ }^{3}$ Our focus is on capital taxes to correct pecuniary externalities in an open economy, but the same logic can equally be used in a closed economy, see e.g. Jeanne and Korinek (2013) and Jeanne and Korinek (2018).
} 
a large economy can affect the world interest rate. Depending on the country's net external asset position, policy makers would have the incentive to impose capital inflow controls or capital outflow controls to manipulate the cost of foreign borrowing (see e.g. Costinot et al. (2014), De Paoli and Lipinska (2013), and Heathcote and Perri (2016)). This may have implications for the importance of domestic financial constraints over the economic cycle. Second, in a large country context, capital taxes have international strategic implications, and the response of the foreign country to capital controls policy in the home country must be considered. This leads to a critical question as to whether corrective taxes are chosen at a global level (cooperative) or a national level (Nash). If individual countries choose taxes, then it is not clear that a world equilibrium will be characterized by an efficient correction of the pecuniary externalities implicit in the financial constraint facing households in debt markets. These two features of the large open economy mean that the lessons about macroprudential capital controls that are learned in a small open economy setting may not apply to large emerging market countries like China, Brazil, or India.

This paper explores the determination of capital controls in a two-country general equilibrium model where borrowers in one country may be subject to a binding collateral constraint for a large enough negative shock. Benigno et al. (2016) discuss optimal capital controls to correct a pecuniary externality, but in the context of a small open economy. ${ }^{4}$ We instead consider optimal ex-ante and ex-post capital controls policy in a large open economy, which allows us to analyze the interaction between optimal capital controls to correct pecuniary externalities, and the external effects of capital controls which give rise to terms-of-trade manipulation and strategic interactions in global capital markets. As described above, within this framework we can enrich the standard analysis of capital controls to take account of the different and sometimes conflicting motivations that a policymaker has for imposing capital controls, the spillover effects on other countries, and the welfare implications of non-

\footnotetext{
${ }^{4}$ In this paper we focus on real models, but other papers have considered capital controls models with nominal rigidities, see e.g. Farhi and Werning (2014), Schmitt-Grohe and Uribe (2016) and Devereux et al. (2018). Similarly, Farhi and Werning (2016) and Korinek and Simsek (2016) consider the role of macroprudential policy in a closed economy model with nominal rigidities.
} 
cooperative versus cooperative determination of capital controls. ${ }^{5}$

The model is made deliberately simple to take advantage of key insights into the different mechanisms involved in the determination of the gains and losses to capital controls. There are two countries (home and foreign) and three periods. In the home country there exist borrowers and lenders. Borrowers have pre-existing debt, and borrow in order to smooth consumption. Borrowers face an occasionally binding borrowing constraint, where total debt cannot exceed the market value of their endowment. One key feature is that the value of collateral is endogenous. By imposing capital outflow taxes the policymaker can raise the value of collateral and thus loosen a binding borrowing constraint.

In this stylized model, a negative shock to home country endowments occurs in the middle period. Thus there is a pre-shock period, a shock period, and a post-shock period. We consider optimal capital controls policy in both the shock period (crisis management capital controls) and the pre-shock period (prudential capital controls). Our results are focused around the experiment of a temporary negative shock to the home country. We fully characterize both the optimal capital control response, the nature of cross country spillovers from this policy, and the equilibrium where both the home and foreign countries react to the home country shock by choosing optimal capital flow taxes.

We begin with capital controls capital controls set after the realization of the shock. In the case of a small shock, where the borrowing constraint does not bind, the home country will borrow on international capital markets, and the optimal capital control response is to impose a capital inflow tax. This will reduce the current account deficit, reduce the world interest rate, and thus improve the country's terms-of-trade. By the same token, this imposes a negative spillover impact on the foreign country. In a Nash equilibrium, the foreign country will respond with a capital outflow tax, which in turn imposes a negative welfare spillover on the home country.

\footnotetext{
${ }^{5}$ The fact that through capital controls policy the large economy can manipulate the world interest rate provides the violation of Korinek's "first welfare theorem for open economies" and makes international policy coordination beneficial (see Korinek (2017)).
} 
But if the negative shock in the home country is sufficiently large, the borrowing constraint will bind. In that case, the home country faces conflicting incentives in setting capital taxes. A capital inflow tax will reduce the world interest rate and improve the home country's terms-of-trade. But this will reduce net capital inflows, and thus cause a fall in the value of domestic collateral, tightening the borrowing constraint. By contrast, a capital outflow tax raises the value of collateral. Due to this trade-off, the home country's initial inflow tax will reverse direction, and for a large enough shock, the inflow tax becomes an outflow tax, and the policymaker's primary motivation switches from terms-of-trade manipulation to crisis management.

The effectiveness of capital controls for crisis management is reduced because the policymaker must choose between these two conflicting motivations. Because policymakers are trying to also manipulate the terms-of-trade, the capital outflow tax is less than it would be if the only concern was to relax the borrowing constraint.

This tension between terms-of-trade manipulation and crisis-management is present even when the home country policymaker sets taxes unilaterally, that is, with no response from the foreign country. When the the foreign policymaker also responds, the outcome is worse. Foreign policymakers manipulate their terms-of-trade by taxing outflows, which leads to a fall in net inflows into the home country, further tightening the home country borrowing constraint. In a non-cooperative (Nash) equilibrium, welfare spillovers become asymmetric, the home outflow tax set to loosen the borrowing constraint benefits the foreign country, while the foreign outflow tax to manipulate the terms-of-trade lowers home country welfare.

Thus, in a Nash equilibrium the home country, and the world as a whole, will be worse off than in an environment where neither country imposes capital controls. The asymmetric nature of spillovers therefore means that in the absence of policy cooperation, a country which suffers a financial crisis is effectively unable to successfully use capital controls for crisis management purposes.

By contrast, when the two countries choose capital taxes cooperatively, the cooperative 
policy maker ignores the terms-of-trade motive for capital controls, and focuses on crisis management. In this case, the home country alone will impose a capital outflow tax when the borrowing constraint binds, and both countries can gain from effective use of capital controls.

This same tension between the competing motives for capital controls is equally present when controls are chosen before the realization of the shock. In anticipation of a negative shock and binding borrowing constraints in the future, home country agents will engage in precautionary saving (as in Mendoza (2010)). This leads the home country to be a net creditor. As a result, when setting ex-ante capital controls, the home policymaker will manipulate the terms-of-trade by imposing capital outflow controls to raise the world interest rate. But these capital outflow controls will reduce these precautionary savings, making the country more vulnerable to a binding collateral constraint when the shock occurs. Thus while the ex-ante capital controls are meant to be prudential, the tension between termsof-trade manipulation and the prudential motive leads to more debt and less precautionary savings than would occur if ex-ante capital controls were purely prudential.

When we put both of results together, we conclude that whether from prudential motives, or crisis management motives, a country that is vulnerable to financial crises cannot gain from the use of capital controls in the absence of effective international policy cooperation. But in addition to that, we find that non-cooperative (or unilateral) determination of capital controls itself actually increases the frequency of financial crises. When capital controls are set to balance among the competing strategic and prudential or crisis management motives, financial crises occur more frequently than in a Laissez Faire environment where no capital controls are used at all. ${ }^{6}$

This paper will proceed as follows. The next section presents the model. The model is a deliberately simple two country, three period model. We characterize optimal capital

\footnotetext{
${ }^{6}$ When studying the effect of time consistent macro-prudential policies, Bianchi and Mendoza (2018) also find that the probability of a crisis is endogenous to the type of policy chosen. As shown by Davila and Korinek (2017), crises can still happen even under an efficient allocation, but they do tend to be less frequent and less severe.
} 
tax policy in section 3 under a variety of strategic scenarios for policy-making. The results in this section can be shown analytically. In section 4 we present numerical results where we solve this model for the equilibrium allocations under different capital tax scenarios and quantify the welfare effects and spillovers of different capital control regimes. The final section concludes.

\section{Model}

We develop a three-period, two-country ('home' and 'foreign') model. Agents derive utility from the consumption of a tradable good $X_{0}$ in period 0 , a tradable good $X_{1}$ and a nontradable good $Y$ in period 1 , and a tradable good $X_{2}$ in period 2. The countries are not symmetric. While both are endowed with initial stocks of goods $X_{0}, X_{1}, Y, X_{2}$, in period 1 , the home country's endowments of $X_{1}$ and $Y$ are subject to a country specific shock, realized at the beginning of period 1 .

In addition, the home country's population is divided between borrowers and savers. Borrowers begin period 0 with an initial stock of debt, held by savers in the same country (so initially, countries have balanced external accounts). Borrowers also face a constraint limiting their new debt issue to a fraction of the market value of their endowment in a given period. We choose parameters and endowments so that this constraint may bind only in period 1 following a sufficiently large negative shock.

Since our focus is on spillovers of macro-prudential capital controls from one country, we assume that the foreign country is populated by a representative household that never faces a binding borrowing constraint.

The three types of agents, home country savers, home country borrowers, and foreigners are indexed by $i=s, b, *$.

Agents maximize utility, described as follows: 


$$
U^{i}=u\left(c_{0}^{i}\right)+E\left(\beta u\left(c_{1}^{i}\right)+\beta^{2} u\left(c_{2}^{i}\right)\right)
$$

where $u(c)=\frac{c^{1-\sigma}}{1-\sigma}$, and $E$ is the expectations operator, taken over the distribution of the endowment shock in period 1. Consumption in period 1 is a Cobb-Douglas combination of a tradable good $X$ and a non-tradable good $Y$. Period 0 and period 2 consumption is simply consumption of the tradable good $X$ :

$$
\begin{aligned}
c_{0}^{i} & =c_{0, X}^{i} \\
c_{1}^{i} & =\frac{1}{\alpha^{\alpha}(1-\alpha)^{1-\alpha}}\left(c_{1, X}^{i}\right)^{\alpha}\left(c_{1, Y}^{i}\right)^{1-\alpha} \\
c_{2}^{i} & =c_{2, X}^{i}
\end{aligned}
$$

The only source of uncertainty is a country-specific shock, A, to home country endowments in the period 1. Foreign endowments are doubled to reflect the fact that there are two (normalized) home country agents but only one foreign country agent.

The endowments are described by:

$$
\begin{aligned}
& x_{0}^{i}=X_{0} \text { and } x_{1}^{i}=A X_{1}, y_{1}^{i}=A Y \text { and } x_{2}^{i}=X_{2} \text { for } i=s, b \\
& x_{0}^{i}=2 X_{0} \text { and } x_{1}^{i}=2 X_{1}, y_{1}^{i}=2 Y \text { and } x_{2}^{i}=2 X_{2} \text { for } i=*
\end{aligned}
$$

where the country-specific shock in the first period, $A$, is equal to $1-\varepsilon$, where $\varepsilon$ follows an exponential distribution with rate parameter $0.02 .^{7}$

The period 0,1,2 budget constraints for home country savers are given by the following:

\footnotetext{
${ }^{7}$ This distribution is chosen simply to ensure that in our benchmark calibration, the probability of a binding constraint is $10 \%$.
} 


$$
\begin{aligned}
c_{0, X}^{s}+\frac{B_{0}^{s}}{R_{0}}+\left(1+\tau_{0}\right) \frac{F_{0}}{R_{0}^{W}}+\Gamma_{0} & =x_{0}^{s}+\bar{B}^{s} \\
c_{1, X}^{s}+p c_{1, Y}^{s}+\frac{B_{1}^{s}}{R_{1}}+\left(1+\tau_{1}\right) \frac{F_{1}}{R_{1}^{W}}+\Gamma_{1} & =x_{1}^{s}+p y_{1}^{s}+B_{0}^{s}+F_{0} \\
c_{2, X}^{s} & =x_{2}^{s}+B_{1}^{s}+F_{1}-T
\end{aligned}
$$

where $B_{t}$ represents domestic bonds (held by borrowers and savers in the home country) and $F_{t}$ represents foreign bonds (held by home country savers and foreign households) in period $t=0,1{ }^{8}$

$R_{t}$ is the interest rate on domestic bonds and $R_{t}^{W}$ is the interest rate on international bonds. The tax rate $\tau_{t}$ is a policy variable and represents taxes on international borrowing and lending, and $\Gamma_{t}=-\tau_{t} \frac{F_{t}}{R_{t}^{W}}$ is the lump sum rebate of that tax revenue. The price $p$ is the relative price of the non-traded good $Y$ in the home country.

The variable $T$ represents a lump sum transfer from savers to borrowers in the home country. This second period transfer from savers to borrowers is adjusted to ensure that the policymaker has no incentive to use the policy instrument $\tau$ for redistribution from savers to borrowers. ${ }^{9}$ Further details about this transfer are presented in the next section.

The budget constraints for home country borrowers are given by:

\footnotetext{
${ }^{8}$ We assume that borrowers do not have direct access to international capital markets, and instead sell bonds to domestic savers. This makes the exposition of the results somewhat easier. Since savers have the option of holding foreign assets or borrower's bonds, the two assets must have the same (after tax) rate of return for domestic agents. Hence the interest rate paid by borrowers in domestic transactions with savers equals that paid or received by savers in international borrowing or lending. We could instead assume that borrowers directly sell bonds to international or domestic savers. If borrowers faced the same capital flow taxes as savers, and in addition the borrowing constraint reflected the borrowers adjusted (for capital controls) cost of debt, then all our results would be unchanged.

${ }^{9}$ Since borrowers begin with a stock of debt, they have a lower wealth level and a higher marginal utility of consumption. Thus, absent transfers, the policy maker would have an incentive to use $\tau$ to redistribute from savers to borrowers.
} 


$$
\begin{aligned}
c_{0, X}^{b}+\frac{B_{0}^{b}}{R_{0}} & =x_{0}^{b}+\bar{B}^{b} \\
c_{1, X}^{b}+p c_{1, Y}^{b}+\frac{B_{1}^{b}}{R_{1}} & =x_{1}^{b}+p y_{1}^{b}+B_{0}^{b} \\
c_{2, X}^{b} & =x_{2}^{b}+B_{1}^{b}+T
\end{aligned}
$$

The budget constraints for foreign country households are given by:

$$
\begin{aligned}
c_{0, X}^{*}+\frac{B_{0}^{*}}{R_{0}^{*}}+\left(1+\tau_{0}^{*}\right) \frac{F_{0}^{*}}{R_{0}^{W}}+\Gamma_{0}^{*} & =x_{0}^{*} \\
c_{1, X}^{*}+p^{*} c_{1, Y}^{*}+\frac{B_{1}^{*}}{R_{1}^{*}}+\left(1+\tau_{1}^{*}\right) \frac{F_{1}^{*}}{R_{1}^{W}}+\Gamma_{1}^{*} & =x_{1}^{*}+p^{*} y_{1}^{*}+B_{0}^{*}+F_{0}^{*} \\
c_{2, X}^{*} & =x_{2}^{*}+B_{1}^{*}+F_{1}^{*}
\end{aligned}
$$

Bond market clearing conditions are given by:

$$
\bar{B}^{s}+\bar{B}^{b}=0 ; B_{t}^{s}+B_{t}^{b}=0 ; B_{t}^{*}=0 ; \text { and } F_{t}+F_{t}^{*}=0 \text { for } t=0,1
$$

The only difference between home country borrowers and savers is that borrowers begin period 0 with a stock of debt held by home country savers, $\bar{B}^{s}>0$.

Due to limited enforcement of debt contracts, home country borrowers face a borrowing constraint given by:

$$
-\frac{B_{1}^{b}}{R_{1}} \leq \kappa\left(x_{1}^{b}+p y_{1}^{b}\right)
$$

The multiplier on the borrowing constraint is given by $\mu$.

Finally, market clearing conditions are given by: 


$$
\begin{aligned}
\sum_{i} c_{t, X}^{i} & =\sum_{i} x_{t}^{i} \text { for } t=0,1,2 \\
c_{1, Y}^{s}+c_{1, Y}^{b} & =y_{1}^{s}+y_{1}^{b} \\
c_{1, Y}^{*} & =y_{1}^{*}
\end{aligned}
$$

\subsection{Capital controls versus domestic subsidies}

Our analysis is focused on the optimality of capital controls in large economies with financial frictions. Capital controls place a wedge between domestic borrowers or lenders and the world interest rate. As noted above, the impact of capital controls would be the same if home country borrowers were to directly access world capital markets. But an alternative possibility for macro-prudential policy would be to directly impose a tax on borrowing by the home country borrowers. This would drive a wedge between the returns to home country

borrowers and savers. We choose to focus on the implications of a tax imposed on external rather than internal borrowing for a number of reasons. First, it implies that all home country agents face the same returns, which avoids having to deal with the heterogeneous impact of taxes on home welfare. In fact, a tax or subsidy on home country borrowers would have most of the same effects, (through terms of trade and pecuniary externalities) as the capital controls explored in this paper, while additionally affecting borrowers and savers differentially. But more importantly, the motivation of our paper is to explore the case for capital controls, which are by definition a tax or subsidy on external borrowing. In the absence of financial frictions, capital controls can be useful only for terms of trade manipulation. The main focus of the analysis is to explore how this rationale for capital controls interacts and conflicts with their usage for alleviating financial frictions. 


\section{Analytical results}

We first provide an analytical characterization of the choice of capital controls under alternative strategic settings. Without international cooperation, the central bank imposes the capital tax $\tau_{t}$ on the purchase of foreign bonds $F_{t}$ so as to maximize the sum of saver and borrower utility, taking as given the capital tax imposed by the foreign central bank, $\tau_{t}^{*}$. Period 0 capital taxes $\tau_{0}$ are chosen based on a forecast of the capital taxes chosen by the period 1 authorities. All period 0,1, and 2 variables except for the capital taxes $\tau$ are determined in competitive equilibrium. The description of the competitive equilibrium is set out in the appendix. In the appendix we also characterize the planner's problem for the optimal period 0 and period 1 capital taxes $\tau$.

\subsection{Period 1 Capital Controls: Crisis management}

We begin by describing the setting of capital controls in period 1, after the realization of the home country productivity shock, conditional on the outstanding stock of net foreign assets $F_{0}$ and the initial level of within-home country borrowers debt $-B_{0}$.

The home country planner will set $\tau_{1}$ to maximize $W\left(\tau_{1} ; \tau_{1}^{*}, A, \mathbf{V}_{0}\right)=U^{b}\left(\tau_{1} ; \tau_{1}^{*}, A, \mathbf{V}_{0}\right)+$ $U^{s}\left(\tau_{1} ; \tau_{1}^{*}, A, \mathbf{V}_{0}\right)$ and the foreign country planner will set $\tau_{1}^{*}$ to maximize $W^{*}\left(\tau_{1}^{*} ; \tau_{1}, A, \mathbf{V}_{0}\right)=$ $U^{*}\left(\tau_{1}^{*} ; \tau_{1}, A, \mathbf{V}_{0}\right)$, where $\mathbf{V}_{0}$ is a vector of all period 0 variables. The first order condition of the home policymaker's maximization problem is (where we have already made the substitution $\left.B_{1}=B_{1}^{b}=-B_{1}^{s}\right)$ :

$$
\begin{aligned}
\frac{d W}{d \tau_{1}}= & \beta R_{1}\left(-\lambda_{2}^{b}\left(c_{1, Y}^{b}-y_{1}^{b}\right)-\lambda_{2}^{s}\left(c_{1, Y}^{s}-y_{1}^{s}\right)\right) \frac{d p}{d \tau_{1}} \\
& +\beta\left(\lambda_{2}^{b}-\lambda_{2}^{s}\right) \frac{B_{1}}{R_{1}} \frac{d R_{1}}{d \tau_{1}} \\
& +\left(-\lambda_{1}^{s} \frac{1}{R_{1}^{w}}+\beta \lambda_{2}^{s}\right) \frac{d F_{1}}{d \tau_{1}}+\lambda_{1}^{s} \frac{F_{1}}{\left(R_{1}^{w}\right)^{2}} \frac{d R_{1}^{w}}{d \tau_{1}} \\
& +\left(\kappa y_{1}^{b}-\left(c_{1, Y}^{b}-y_{1}^{b}\right)\right) \mu \frac{d p}{d \tau_{1}}
\end{aligned}
$$


where $\lambda_{t}^{i}$ is the marginal utility of consumption for agent type $i$ in period $t$.

This expression highlights the policymaker's three motives for setting capital taxes $\tau_{1}$ :

1. Domestic redistribution: borrowers are poorer than savers since they begin with an initial level of debt, thus the marginal utility of borrowers is greater than the marginal utility of savers.

2. Manipulate the terms-of-trade: making imports cheaper and exports more expensive, which in this model, with one traded good, implies a desire for a net creditor (when $\left.F_{1}^{h}>0\right)$ to raise the world interest rate $R_{1}^{w}$ and for a net debtor to reduce the world interest rate.

3. Crisis management: using capital controls to affect the relative price of non-traded goods and thus the tightness of the borrowing constraint.

The first two lines in (1) represent the planner's use of $\tau_{1}$ for domestic redistribution. This can take place through two channels. The first involves changing $p$, and thus affecting saver and borrower welfare due to differences in consumption and endowments of the nontraded good, $c_{1, Y}^{b}-y_{1}^{b}$ and $c_{1, Y}^{s}-y_{1}^{s}$. The second channel is through changes in $R_{1}$, thus affecting saver and borrower welfare, given that borrowers have outstanding debt $B_{1}<0$. The use of the transfer $T$ is designed to eliminate the planner's motive to use $\tau$ for domestic redistribution. As we discuss in the appendix, this transfer in the second period is chosen to equate saver and borrower marginal utilities of consumption in the second period, $\lambda_{2}^{b}=\lambda_{2}^{s}$. Thus the transfer will eliminate the first two lines of this derivative.

The third line in (1) captures the planner's use of $\tau_{1}$ for terms-of-trade manipulation. It depends on the level of home country net exports, $F_{1}$, and the ability of $\tau_{1}$ to affect the world interest rate (the price of net exports), $\frac{d R_{1}^{w}}{d \tau_{1}}$. If $F_{1}=0$, then, based on this channel alone, the optimal capital tax would be zero.

Finally, the fourth line in equation (1) represents the crisis management motive for the use of $\tau_{1}$. This channel is relevant only when the constraint is binding and thus $\mu>0$. 
By increasing $\tau_{1}$ the planner will reduce exports of the traded good in the first period and thus (by increasing period 1 consumption) increase the relative price of the non-traded good, $\frac{d p}{d \tau_{1}}>0$. A higher price of the non-traded good loosens the home country borrowing constraint by increasing the value of the borrower's collateral, $\kappa y_{1}^{b}$. But at the same time the increase in $p$ will either tighten or loosen the borrowing constraint depending on whether the borrower consumes more or less of the non-traded good than their endowment, $c_{1, Y}^{b}-y_{1}^{b}$.

Since the first two lines in (1) cancel out due to the transfer, the maximization condition reduces to (after factoring in the equilibrium conditions $R_{1}=\frac{R_{1}^{w}}{1+\tau_{1}}$ and the saver's first order condition with respect to $\left.F_{1}\right)$ :

$$
\frac{d W}{d \tau_{1}}=\frac{\lambda_{1}^{s}}{R_{1}^{w}}\left(\tau_{1} \frac{d F_{1}}{d \tau_{1}}+\frac{F_{1}}{R_{1}^{w}} \frac{d R_{1}^{w}}{d \tau_{1}}\right)+\left(\kappa y_{1}^{b}-\left(c_{1, Y}^{b}-y_{1}^{b}\right)\right) \mu \frac{d p}{d \tau_{1}}=0
$$

\subsubsection{Optimal capital taxes when the borrowing constraint is not binding}

When the borrowing constraint is slack, the optimal capital tax for the home country becomes a standard example of a monopoly 'optimal tariff problem'. The first order condition for the home government may be reduced to the following:

$$
\frac{d W}{d \tau_{1}}=\frac{\lambda_{1}^{s}}{R_{1}^{w}}\left(\tau_{1} \frac{d F_{1}}{d \tau_{1}}+\frac{F_{1}}{R_{1}^{w}} \frac{d R_{1}^{w}}{d \tau_{1}}\right)=0
$$

The first term captures the first order effect of a home capital tax on savers utility through its effect on net foreign assets $F$, the second term captures the welfare effect of the tax through its effect on the world interest rate. We can rewrite (2) as:

$$
\tau_{1}=-\frac{F_{1}}{R_{1}^{w}} \frac{d R_{1}^{w}}{d F_{1}}
$$

We first consider the unilateral case, that is where $\tau^{f}=0$.

Note that $\frac{d R_{1}^{w}}{d F_{1}}<0$, since a decrease in home country net savings $F_{1}$ leads to an increase in the world interest rate $R_{1}^{w}$. When the home country receives a substantial negative shock 
in period 1 , we have $F_{1}<0$. Thus, the home government will levy a capital inflow tax (set $\left.\tau_{1}<0\right)$ when the home country receives a negative shock and the borrowing constraint does not bind.

Now assume that the foreign country planner also sets an optimal capital tax. The foreign optimal tax may be expressed as

$$
\tau_{1}^{*}=-\frac{F_{1}^{*}}{R_{1}^{w}} \frac{d R_{1}^{w}}{d F_{1}^{*}}
$$

Since $\frac{d R_{1}^{w}}{d F_{1}^{*}}<0$, and $F_{1}^{*}>0$ when the home country receives a negative shock in the first period, condition (4) indicates that the foreign country will set a capital outflow tax, which is designed to raise the world interest rate and improve the foreign terms-of-trade.

Without a binding borrowing constraint, therefore, we have the conventional result that borrowers tax inflows while lenders tax outflows.

Result 1 In a non-cooperative equilibrium without a binding borrowing constraint, when the home country receives a negative shock the home country taxes inflows and the foreign country taxes outflows. $\tau_{1}<0, \tau_{1}^{*}>0$.

Welfare Spillovers From the welfare functions above, we can also compute the welfare spillovers of capital taxes across countries. From the appendix we obtain:

$$
\frac{d W}{d \tau_{1}^{*}}=\frac{\lambda_{1}^{s}}{R_{1}^{w}}\left(\tau_{1} \frac{d F_{1}}{d \tau_{1}^{*}}+\frac{F_{1}}{R_{1}^{w}} \frac{d R_{1}^{w}}{d \tau_{1}^{*}}\right)
$$

The first term is negative, since $\frac{d F_{1}}{d \tau_{1}^{*}}>0$ - when $\tau_{1}<0$, home country capital inflows are inefficiently low to begin with - and an increase in the foreign capital outflow tax will exacerbate this inefficiency. The second term is also negative, since the capital outflow tax imposed by the foreign country drives up world interest rates and imposes a negative wealth effect on the home economy when $F_{1}<0$.

It can equally be shown that the welfare spillovers from home capital inflow taxes to the 
foreign country are negative. When the home country receives a negative shock, it imposes a capital inflow tax. This reduces the world interest rate, and reduces the foreign country's demand for bonds. Both factors reduce foreign welfare.

This brings us to our second generalized result:

Result 2 In a non-cooperative equilibrium where the home country receives the bad shock, and the borrowing constraint is slack, welfare spillovers of home and foreign capital taxes are negative in both directions.

Best Response Functions Conditions (3) and (4) can be used to derive best response functions. From condition (3), we have the optimal $\tau_{1}$ as a function of $\tau_{1}^{*}$

$$
\tau_{1}\left(\tau_{1}^{*}\right)=-\frac{F_{1}}{R_{1}^{w}} \frac{d R_{1}^{w}}{d F_{1}}
$$

Assuming that the second derivative, $\frac{d^{2} R_{1}^{w}}{d F_{1} d \tau_{1}^{*}}$ is second order and small, the derivative of $\tau_{1}\left(\tau_{1}^{*}\right)$ is:

$$
\frac{d \tau_{1}}{d \tau_{1}^{*}}=-\left(\frac{\frac{d F_{1}}{d \tau_{1}^{*}}}{R_{1}^{w}}-\frac{F_{1}}{\left(R_{1}^{w}\right)^{2}} \frac{d R_{1}^{w}}{d \tau_{1}^{*}}\right) \frac{d R_{1}^{w}}{d F_{1}}
$$

If the home country receives a negative shock then $F_{1}<0$ and $\frac{d F_{1}}{d \tau_{1}^{*}}>0$, then $\frac{d \tau_{1}}{d \tau_{1}^{*}}>0$. That is, the home country best response function is upward sloping.

Following the same logic, the foreign country best response function is written as

$$
\frac{d \tau_{1}^{*}}{d \tau_{1}}=-\left(\frac{\frac{d F_{1}^{*}}{d \tau_{1}}}{R_{1}^{w}}-\frac{F_{1}^{*}}{\left(R_{1}^{w}\right)^{2}} \frac{d R_{1}^{w}}{d \tau_{1}}\right) \frac{d R_{1}^{w}}{d F_{1}^{*}}
$$

The first term inside the parenthesis is positive, while the second term is negative, since $F_{1}^{*}$ is positive when the home country receives the bad shock. Thus, it is not possible to unambiguously determine the slope of the foreign country best response function from this expression. In practice however, as described more fully in section 4 below, we find that the 
foreign best response function is always upward sloping.

\subsubsection{Optimal capital taxes when the borrowing constraint binds}

Now we move on to analyze the case where the bad shock is sufficiently large that the borrowing constraint binds in the home country. In this case condition (2) becomes:

$$
\frac{d W}{d \tau_{1}}=\frac{\lambda_{1}^{s}}{R_{1}^{w}}\left(\tau_{1} \frac{d F_{1}}{d \tau_{1}}+\frac{F_{1}}{R_{1}^{w}} \frac{d R_{1}^{w}}{d \tau_{1}}\right)+\left(\kappa y_{1}^{b}-\left(c_{1, Y}^{b}-y_{1}^{b}\right)\right) \mu \frac{d p}{d \tau_{1}}=0
$$

which becomes

$$
\tau_{1}=-\frac{F_{1}}{R_{1}^{w}} \frac{d R_{1}^{w}}{d F_{1}}-R_{1}^{w}\left(\kappa y_{1}^{b}-\left(c_{1, Y}^{b}-y_{1}^{b}\right)\right) \frac{\mu}{\lambda_{1}^{s}} \frac{d p}{d F_{1}}
$$

When the constraint binds, $\mu>0$, and we have an additional term, $-R_{1}^{w}\left(\kappa y_{1}^{b}-\left(c_{1, Y}^{b}-y_{1}^{b}\right)\right) \frac{\mu}{\lambda_{1}^{s}} \frac{d p}{d F_{1}}$, in the expression for the optimal $\tau_{1}$.

An increase in $\tau_{1}$ will lead to increased imports and increased consumption of the traded good in the first period, $\frac{d F_{1}}{d \tau_{1}}<0$. Increased consumption of the traded good will raise the relative price of the non-traded good, $\frac{d p}{d F_{1}}>0$. This implies that this additional term in the expression for $\tau^{h}$ is positive, as long as borrowers' consumption of the non-traded good is not more than a multiple of their endowment, $(1+\kappa) y_{1}^{b}>c_{1, Y}^{b}$. As a result, a binding borrowing constraint will shift the incentive for the home to set $\tau_{1}<0$ towards setting $\tau_{1}>0$. With a binding borrowing constraint, the terms-of-trade motive for to set an inflow tax as a net external borrower is in conflict with the crisis-management motive to tax capital outflows so as to increase the value of domestic collateral.

Result 3 When the home country receives a negative shock, and the borrowing constraint binds, in a non-cooperative equilibrium, the home country will set a capital flow tax that balances the incentive to improve the terms-of-trade (an inflow tax) against the incentive to relax the domestic borrowing constraint (an outflow tax). The foreign country will continue to set an outflow tax to improve its terms-of-trade. 
Result 3 also implies that welfare spillovers of capital taxes may be very different in the case of binding domestic borrowing constraints. We have shown above that a capital outflow tax, $\tau_{1}>0$, in the home country will have a positive welfare spillover on the foreign country, since a rise in $\tau_{1}$ raises the world interest rate, and the foreign country is a net external creditor in the case where the home country receives a negative shock. Thus, with a sufficiently large negative shock that leads to a binding home country borrowing constraint, the home country's capital tax is beneficial for foreign welfare. On the other hand, the welfare spillover from the foreign to the home country continues to be negative. In the case of a binding home borrowing constraint, the spillovers from a foreign capital tax to the home country become

$$
\frac{d W}{d \tau_{1}^{*}}=\frac{\lambda_{1}^{s}}{R_{1}^{w}}\left(\tau_{1} \frac{d F_{1}}{d \tau_{1}^{*}}+\frac{F_{1}}{R_{1}^{w}} \frac{d R_{1}^{w}}{d \tau_{1}^{*}}\right)+\left(\kappa y_{1}^{b}-\left(c_{1, Y}^{b}-y_{1}^{b}\right)\right) \mu \frac{d p}{d \tau_{1}^{*}}
$$

The $\frac{\lambda_{1}^{s}}{R_{1}^{w}}\left(\tau_{1} \frac{d F_{1}}{d \tau_{1}^{*}}+\frac{F_{1}}{R_{1}^{w}} \frac{d R_{1}^{w}}{d \tau_{1}^{*}}\right)$ is negative, as before. But now there is an additional negative term, $\left(\kappa y_{1}^{b}-\left(c_{1, Y}^{b}-y_{1}^{b}\right)\right) \mu \frac{d p}{d \tau_{1}^{*}}$. This captures the effect of a rise in the foreign capital tax in tightening the home country borrowing constraint. An increase in $\tau_{1}^{*}$, by raising the world interest rates, reduces consumption of the traded good in the home country, leading to a fall in the relative price of the non-traded good, $\frac{d p}{d \tau_{1}^{*}}<0$. This lowers the value of collateral and thus tightens the borrowing constraint.

From this we may establish the following:

Result 3 In a non-cooperative equilibrium, with a binding borrowing constraint in the home country and a sufficiently negative shock, welfare spillovers are asymmetric. The home country's capital outflow tax benefits the foreign country, while the foreign country's outflow tax reduces home country welfare. 


\subsubsection{Capital Taxes with International Cooperation}

How does the possibility of international policy cooperation alter these results? In optimal cooperative policy the policymaker sets $\tau_{1}$ to maximize the sum of home and foreign country welfare while keeping $\tau_{1}^{*}=0$.

We define the objective function for the cooperative equilibrium as

$$
W^{w}=W+W^{*}
$$

Using (10), we may derive the first order condition in the case without binding borrowing constraints as

$$
\frac{d W^{w}}{d \tau_{1}}=\frac{\lambda_{1}^{s}}{R_{1}^{w}}\left(\tau_{1} \frac{d F_{1}}{d \tau_{1}}+\frac{F_{1}}{R_{1}^{w}} \frac{d R_{1}^{w}}{d \tau_{1}}\right)+\frac{\lambda_{1}^{*}}{R_{1}^{w}}\left(\frac{F_{1}^{*}}{R_{1}^{w}} \frac{d R_{1}^{w}}{d \tau_{1}}\right)=0
$$

which reduces to:

$$
\tau_{1}=-\left(1-\frac{\lambda_{1}^{*}}{\lambda_{1}^{s}}\right) \frac{F_{1}}{R_{1}^{w}} \frac{d R_{1}^{w}}{d F_{1}}
$$

Notice that this is the optimal $\tau_{1}$ that would maximize home country welfare from equation (6) the last section multiplied by $1-\frac{\lambda_{1}^{*}}{\lambda_{1}^{s}}$. When the two countries are symmetric and the marginal utility in the foreign country is equal to the marginal utility in the home country, the optimal cooperative $\tau_{1}=0$. When the home country receives a negative shock and thus $\lambda_{1}^{s}>\lambda_{1}^{*}$, the optimal cooperative $\tau_{1}<0$, as optimal cooperative policy tries to manipulate the terms-of-trade in favor of the country that received the negative shock. But the optimal cooperative $\tau_{1}$ is far smaller in absolute value than the $\tau_{1}$ that would maximize home country welfare alone. In fact, as we will see in the numerical results in the next section, when the borrowing constraint does not bind, the optimal cooperative $\tau_{1} \approx 0$. Thus we have:

Result 4 In the absence of binding borrowing constraints, the cooperative choice of capital taxes will set $\tau_{1} \approx 0$. 
Cooperation with binding borrowing constraints When the borrowing constraint in the home country is binding, condition (11) is becomes

$$
\frac{d W^{w}}{d \tau_{1}}=\frac{\lambda_{1}^{s}}{R_{1}^{w}}\left(\tau_{1} \frac{d F_{1}}{d \tau_{1}}+\frac{F_{1}}{R_{1}^{w}} \frac{d R_{1}^{w}}{d \tau_{1}}\right)+\left(\kappa y_{1}^{b}-\left(c_{1, Y}^{b}-y_{1}^{b}\right)\right) \mu \frac{d p}{d \tau_{1}^{*}}+\frac{\lambda_{1}^{*}}{R_{1}^{w}}\left(\frac{F_{1}^{*}}{R_{1}^{w}} \frac{d R_{1}^{w}}{d \tau_{1}}\right)=0
$$

which reduces to:

$$
\tau_{1}=-\left(1-\frac{\lambda_{1}^{*}}{\lambda_{1}^{s}}\right) \frac{F_{1}}{R_{1}^{w}} \frac{d R_{1}^{w}}{d F_{1}}-R_{1}^{w}\left(\kappa y_{1}^{b}-\left(c_{1, Y}^{b}-y_{1}^{b}\right)\right) \frac{\mu}{\lambda_{1}^{s}} \frac{d p}{d F_{1}}
$$

The first term in this expression, describing the incentive to manipulate the terms-of-trade in optimal cooperative policy, is approximately zero, as described above. So the optimal cooperative $\tau_{1}$ is positive due to the negative second term in this expression. We note that the optimal $\tau_{1}$ will be higher under cooperative policy than when $\tau_{1}$ is set non-cooperatively. When acting alone, the policymaker balances the competing motives towards lowering $\tau_{1}$ for terms-of-trade manipulation and raising $\tau_{1}$ for crisis management reasons. But since termsof-trade manipulation is effectively zero under cooperation, the cooperative policymaker will set a higher $\tau_{1}$ which is focused on crisis management policy in the home country.

Another way to state this is to recall that there are positive welfare spillovers to the foreign country from raising $\tau_{1}$. The same policy of setting $\tau_{1}>0$ benefits the home country for crisis management reasons and benefits the foreign country for terms-of-trade reasons. When maximizing home country welfare alone the home country policymaker does not internalize this spillover effect. This leads us to our last generalized result:

Result 5 When the home country receives the bad shock and its borrowing constraint binds, the cooperative equilibrium will set $\tau_{1}>0$. The $\tau_{1}$ set in the cooperative equilibrium exceeds the $\tau_{1}$ in the non-cooperative equilibrium. 


\subsection{Period 0 Capital Controls: Prudential}

We now focus on the events in period 0 , before the realization of the shock. In period 0 , home country agents make consumption plans taking into account the possibility that the borrowing constraint in period 1 will bind for home country borrowers.

The home country government may also impose inflow or outflow taxes in period 0 . Period 0 capital taxes $\tau_{0}$ are set before the realization of the shock in period 1 . In period 0 the home country planner will set $\tau_{0}$ to maximize $W\left(\tau_{0} ; \tau_{0}^{*}\right)=U^{b}\left(\tau_{0} ; \tau_{0}^{*}\right)+U^{s}\left(\tau_{0} ; \tau_{0}^{*}\right)$ and the foreign country planner will set $\tau_{0}^{*}$ to maximize $W^{*}\left(\tau_{0}^{*} ; \tau_{0}\right)=U^{*}\left(\tau_{0}^{*} ; \tau_{0}\right)$. Capital taxes in period 0 are chosen taking as given the distribution of endowment shocks in period 1, as well as the endogenous response of period 1 capital taxes, depending on the degree of cooperation in capital tax choice that will pertain in period 1.

In the appendix we derive the optimal period 0 capital tax, $\tau_{0}$, chosen by the home country planner in a non-cooperative period 0 equilibrium. It may be expressed as:

$$
\begin{aligned}
\tau_{0}= & -\frac{F_{0}}{R_{0}^{w}} \frac{d R_{0}^{w}}{d F_{0}}-E\left(\frac{R_{0}^{w}}{\lambda_{0}^{s}} \frac{\lambda_{1}^{s}}{R_{1}^{w}}\left(\tau_{1} \frac{d F_{1}}{d F_{0}}+\frac{F_{1}}{R_{1}^{w}} \frac{d R_{1}^{w}}{d F_{0}}\right)\right) \\
& -E\left(\left(\kappa y_{1}^{b}-\left(c_{1, Y}^{b}-y_{1}^{b}\right)\right) \mu \frac{d p}{d F_{0}}\right)-E\left(\beta \mu \frac{B_{0}}{R_{0}} \frac{d R_{0}}{d F_{0}}\right)
\end{aligned}
$$

Equation (15) has four expressions on the right hand side. The first expression describes the pure terms of trade manipulation channel, since it represents the negative of the elasticity of the world interest rate in period 0 with respect to the home country net asset position in

period $0,-\frac{F_{0}}{R_{0}^{w}} \frac{d R_{0}^{w}}{d F_{0}}$. This is the same term that appeared in the expression for the optimal period 1 capital tax $\tau_{1}$, except here it reflects the elasticity of the period 0 interest rate rather than the period 1 interest rate.

In period 1 , after the shock, the home country becomes a net debtor, $F_{1}<0$, and the optimal $\tau_{1}$ for terms-of-trade manipulation is negative. However in the period 0 , before the shock, home country agents engage in precautionary saving (as shown in the quantitative section below), and thus $F_{0}>0$. Thus the optimal $\tau_{0}$ for period 0 terms-of-trade manip- 
ulation is positive. A positive $\tau$ restricts the degree of precautionary saving by the private sector, driving up the world interest rate in time period 0, thus benefiting home savers.

The second expression in equation (15) captures the effect of a time period 0 tax on welfare in time period 1 through its impact on the world interest rate, and through its indirect effect on net external assets $F_{1}$ in time period 1 . This expression is comprised of two parts. The first part, $\tau_{1} \frac{d F_{1}}{d F_{0}}$ captures the fact that time 1 capital controls, ceteris paribus, impose an inefficiency in private sector external borrowing, and it may be desirable to manipulate $F_{0}$ in order to correct this. When $\tau_{1}<0,\left(\tau_{1}>0\right)$ there is an inefficiently high (low) ex-post time 1 saving by the private sector ceteris paribus, and the time zero planner has an incentive to set $\tau>0\left(\tau_{0}<0\right)$ to reduce (raise) $F_{0}$, and thus $F_{1}$, to correct this. The second term captures the strategic incentive of the home country to manipulate the terms of trade terms in period 1. This could be done by generating a change in initial net foreign assets $F_{0}$ to affect the time 1 saving rate, and hence $F_{0}$. But since countries have identical preferences, period 1 savings rates differ only due to capital controls, so the distribution of wealth across countries will have only minor effects on the world interest rate, and so this term will be small.

The third expression in (15) captures the pure macro-prudential role of time 0 capital controls. When $\mu>0$ in period 1 , a higher price of non-traded goods relaxes the borrowing constraint, as we noted above. By setting $\tau_{0}<0$, the home planner can raise $F_{0}$, thus raising consumption in period 1, and pushing up the price of non-traded goods. This highlights a key contrast between macro-prudential capital taxes and capital taxes chosen for crisis management. In period 1 , if the borrowing constraint binds, the planner wishes to boost demand by taxing capital outflows, increasing the price of non-traded goods. But in period 0, ex-ante, anticipating a binding constraint, ceteris paribus, the planner wishes to restrict demand, setting a capital inflow tax for macro-prudential purposes, thus raising initial period 1 net external assets and generating a higher price of non-traded goods.

The final expression in (15), E $\beta \mu \frac{B_{0}}{R_{0}} \frac{d R_{0}}{d F_{0}}$, arises due to distributional factors. When the 
transfer is set to equalize the marginal utility of wealth of home borrowers and lenders in period 2, and the expected value of $\mu$ is positive, home borrowers have a higher marginal utility of wealth in period 1 , and given $B_{0}<0$, the planner wishes to have lower borrowing costs for home borrowers in period 0 , giving an incentive to set $\tau_{0}>0$.

The summary of all the forces driving period 0 capital taxes for the home country represents a conflict between terms of trade manipulation, macro-prudential motives, and distributional motives. In the quantitative analysis below, we show that the critical determinant of the strength of these various motives is the degree of international cooperation in setting capital controls.

In the non-cooperative equilibrium the foreign government will also choose its optimal capital tax in period 0. In the Appendix, we show that the optimal tax for the foreign government is expressed as

$$
\tau_{0}^{*}=-\frac{F_{0}^{*}}{R_{0}^{w}} \frac{d R_{0}^{w}}{d F_{0}^{*}}-E\left(\frac{R_{0}^{w}}{\lambda_{0}^{*}} \frac{\lambda_{1}^{*}}{R_{1}^{w}}\left(\tau_{1}^{*} \frac{d F_{1}^{*}}{d F_{0}^{*}}+\frac{F_{1}^{*}}{R_{1}^{w}} \frac{d R_{1}^{w}}{d F_{0}^{*}}\right)\right)
$$

Given our discussion of (15), expression (16) has a straightforward interpretation. The first term on the right hand side represents foreign country terms of trade manipulation, and given $F_{0}^{*}<0$, this implies that the foreign country has an incentive to set $\tau_{0}^{*}<0$, or set an inflow tax, in period 0 . The second term indicates that, given that the expected value of $\tau_{1}^{*}$ is positive, the time zero foreign country planner has an incentive to further set $\tau_{0}^{*}<0$, increasing initial foreign net foreign assets and thus generating a higher $F_{1}^{*}$.

Finally, in a cooperative equilibrium in period 0 , assuming that governments in period 1 also follow a cooperative equilibrium, it is easy to show that the terms of trade manipulation terms will be absent. In this case, the cooperative equilibrium will set $\tau_{0}^{*}=0$ but $\tau_{0}<0$, since the cooperative planner will wish to encourage an increase in home country net foreign assets brought into period 1 in order to relax the borrowing constraint, in expectation. Given this discussion, we can state the following general results from the analysis of capital taxes set in period 0 . 
Result 6 The motivation to manipulate the terms-of-trade leads the home country policymaker to set $\tau_{0}$ higher than would obtain in a cooperative equilibrium, and this leads to higher home country borrower debt levels in period 0 .

Result 7 The motivation to manipulate the terms-of-trade leads the foreign country policymaker to set $\tau_{0}^{*}$ lower than would obtain in a cooperative equilibrium, and this also leads to higher home country borrower debt levels in period 0 .

\section{A quantitative analysis of capital controls}

\subsection{Calibration}

We now turn to numerical simulations of the model to better highlight the key general results from the last section. When the home country constraint binds in period 1 , the underlying tension between the desire to set $\tau_{1}<0$ for terms-of-trade manipulation and the desire to set $\tau_{1}>0$ for crisis-management leads the home country to suffer significantly more from the absence of cooperation. Furthermore, as we will show, this trade-off actually leads to a higher probability of a binding borrowing constraint relative to a cooperative policy setting.

We will show in addition that in the pre-shock period 0 , the same tension between termsof-trade manipulation and the optimal prudential policy that would minimize the chances of binding borrowing constraint in period 1 leads home country borrowers to hold more debt than they would have if pre-shock policy were set cooperatively.

The initial state in the model is given by the beginning level of home country borrower debt, $\bar{B}^{b}$, and the endowments $X_{0}, X_{1}, Y, X_{2}$. The endowments $X_{0}$ and $X_{2}$ are normalized to one. Given this, the endowments $X_{1}$ and $Y$ are set such that in the symmetric equilibrium

prior to the realization of the shock, the relative price of non-traded goods, $p$, is equal to one and the marginal utility of consumption is equal to one in all 3 periods in the deterministic equilibrium with no shock, $A=1$ (this is achieved when $X_{1}=\alpha$ and $Y=1-\alpha$ ). The 
share of traded goods in the period 1 consumption basket $\alpha=0.2$, and the parameter in the borrowing constraint $\kappa=0.5$.

The country specific productivity $A=1-\varepsilon$, where $\varepsilon$ follows an exponential distribution with rate parameter 0.02 . This implies that the probability that the shock is less than $10 \%$ is 0.993 . The probability that the shock is large enough to cause the home country borrowing constraint to bind is determined by the initial level of bond holdings, $\bar{B}^{b}$. We set $\bar{B}^{b}$ so that in the no tax scenario, $\tau_{t}=\tau_{t}^{*}=0$, this probability is $10 \%$. In our benchmark parameterization this occurs when $\bar{B}^{b}=-0.48755$.

Figures 1-3 plot equilibrium values under various period 1 capital tax scenarios as a function of the size of the negative shock to the home country. In the figures we plot four capital tax scenarios; the unilateral, the non-cooperative, the cooperative, and the no-tax scenario. The figures show equilibrium values as the negative shock in the home country varies from 0 to $10 \%$. The vertical dotted line is the point where the shock starts to bind in the case where there are no capital taxes, $\tau_{t}=\tau_{t}^{*}=0$.

\subsection{Period 1: Crisis management}

Here we discuss the effect of increasing shock size on period 1 capital controls under the four policy regimes. When setting period 1 policy, policymakers take period 0 variables as given. The expectation of the policy regime in period 1 affects precautionary savings behavior in period 0 . To have a clean comparison across the four period 1 policy regimes, we want the initial period 0 variables to start from the same place. We do this by assuming that period 0 savings rates and thus period 1 initial debt levels are based on the period 1 no-tax scenario, i.e. $\tau_{1}=\tau_{1}^{*}=0$. Later we consider the case where period 0 savings decisions, and thus the initial state in period 1 are made in expectation of a certain period 1 policy regime. 


\subsubsection{Unilateral capital controls}

We start with the unilateral case, where the home country imposes capital controls in period 1 without a foreign response. The optimal tax rates are shown in Figure 1. The unilateral case in the figure is based on the numerical derivation of condition (7), assuming that $\tau_{1}^{*}=0$.

The home country will begin period 1 with a small amount of precautionary savings $F_{0}>0$. So for no shock, or a very small negative shock, the home country is a creditor, $F_{1}>0$ and the planner will choose $\tau_{1}>0$, i.e. a capital outflow tax (or inflow subsidy). But as the shock size increases $F_{1}$ falls, and the home country becomes a net debtor, $F_{1}<0$, at a shock size around $1 \%$. At this point, the optimal $\tau_{1}$ for terms-of-trade manipulation becomes negative.

As the shock size increases further, the collateral constraint becomes binding. This occurs in the no tax regime when the shock size is around $4.6 \%$. At this point the home country has an incentive to encourage domestic absorption, increase domestic spending on traded goods, and thereby raise the relative price of non-traded goods and loosening the constraint.

The conflict between terms-of-trade manipulation and crisis management motives for capital controls leads the unilateral capital inflow tax to reverse direction at the point where the constraint starts to bind. As the shock size becomes greater, the crisis management response gradually becomes the main motivation for imposing capital taxes $\tau_{1}$. While at the point where the constraint binds, $\tau_{1}$ is still negative, when the shock size is around $7 \%$, the optimal inflow tax reverses sign, and becomes an outflow tax.

From Figure 3, with a small shock, terms-of-trade manipulation is the main motive for setting capital controls, then unilateral capital controls raise home country welfare but lower foreign country welfare. But at the point where the level of the optimal unilateral $\tau^{h}$ switches from negative to positive, the effect of unilateral capital controls on foreign country welfare switches from negative to positive. Home welfare is higher because the capital outflow tax acts so as to ease the binding internal borrowing constraint. Foreign welfare is higher because the capital outflow tax raises world interest rates and the foreign country is a creditor. 
Thus, in the global context, absent foreign retaliation, crisis management capital controls are uniformly beneficial (relative to the no-tax case). But this conclusion depends on a passive response of the foreign country. In fact, the foreign country will have an incentive to respond to the home capital controls, and the welfare consequences of the home country's use of capital controls are radically different.

\subsubsection{Non-cooperative capital controls}

In a non-cooperative game the home and foreign policy-makers respectively set $\tau_{1}$ and $\tau_{1}^{*}$ to maximize home and foreign welfare. Since the two countries are large open economies, there is a strategic interaction between the two policymakers. Optimal policy in the home country is therefore a schedule of the optimal $\tau_{1}$ for a given $\tau_{1}^{*}$, the best response function $\tau_{1}\left(\tau_{1}^{*}\right)$. Similarly optimal policy in the foreign country is given by the best response function $\tau_{1}^{*}\left(\tau_{1}\right)$, the intersection of these two best response functions in $\left(\tau_{1}, \tau_{1}^{*}\right)$ space is the non-cooperative equilibrium.

The best response functions are plotted in Figure 4. The red lines are the best response of the home policymaker, $\tau_{1}\left(\tau_{1}^{*}\right)$, while the blue lines are for the foreign policymaker, $\tau_{1}^{*}\left(\tau_{1}\right)$. The best response functions are positively sloped. Starting from a point where $F_{1}=0$, a rise in the foreign $\tau_{1}^{*}$ will increase foreign borrowing, raising the world interest rate and making the home country a net creditor. Then the home country would want to impose its own outflow tax $\tau_{1}$, to further raise the world interest rate and improve its terms-of-trade. A similar logic applies to the slope of foreign best response function. The solid best responses represent the case when there is no shock and $A=1$. The dashed lines depict the situation after the home country receives a negative shock. The first panel represents a small shock of $4 \%$, and the home country constraint does not bind for most points $\left(\tau_{1}, \tau_{1}^{*}\right)$ in the plane. The second panel represents a $10 \%$ shock, and the home country constraint binds at every point $\left(\tau_{1}, \tau_{1}^{*}\right)$ in the plane.

When $A=1$, due to the precautionary savings motive in period 0 the home country is a 
net creditor. Relative to an initial position with $F_{1}=0$, this pushes the home best response function to the right and the foreign best response down. The non-cooperative equilibrium then implies $\tau_{1}>0$ and $\tau_{1}^{*}<0$. But as the negative shock gets larger, the home country borrows in the first period to smooth consumption, and as $F_{1}$ falls, the home best response shifts to the left and the foreign best response shifts up. When the shock size is $4 \%$, the home country is a net debtor. However, the constraint does not bind, and the top panel of Figure 4 shows the outcome of the non-cooperative equilibrium where home imposes an inflow tax of about 1 percent and foreign chooses and outflow tax of around the same size.

But with a larger shock to the home country's endowment, the borrowing constraint in the home country will bind. In this case, the home country best response function shifts to the right, since it would wish to impose an outflow tax, raising the price of collateral (nontraded goods) and relaxing the borrowing constraint. It will start gradually shifting to the right as soon as the borrowing constraint binds. The path of the home best response function as the shock size increases can be summarized by the optimal unilateral $\tau_{1}$ in Figure 1 (since the optimal unilateral $\tau_{1}$ is just the point on the best response function when $\tau_{1}^{*}=0$ ). After the constraint starts to bind the home best response shifts to the right, it crosses the best response from the no-shock, $A=1$ case when the shock size is about $8 \%$. And when the shock size is 10\%, as shown in the second panel of Figure 4, it is to the right of the no-shock, $A=1$ best response. By contrast, the foreign best response still shifts upwards, since the foreign country's capital tax is still driven by terms-of-trade motives alone.

The key feature of the second panel is the asymmetry. In the case of the small negative shock, the shifts in the home and foreign best response functions are symmetric. But when the shock is large enough that the home country borrowing constraint is binding, the termsof-trade motive pushes the home best response function to the left and the crisis-management motive pushes the home best response function to the right. Meanwhile the foreign best response shifts up by the terms-of-trade motive alone. As a result in the non-cooperative equilibrium, although both home and foreign may impose outflow taxes, we have $\tau_{1}<\tau_{1}^{*}$. 
Returning to the paths of $\tau_{1}$ and $\tau_{1}^{*}$ in Figure 1, we see that the path of $\tau_{1}$ in the non-cooperative equilibrium is again non-monotonic, as in the unilateral case. By contrast path of the non-cooperative $\tau_{1}^{*}$ is monotonic. The Figure also contrasts the non-cooperative equilibrium with the unilateral case where the foreign country does not respond. Given that its best response function is positively sloped, the home country impose a higher $\tau_{1}$ in the non-cooperative equilibrium than in the unilateral case.

Figure 2 contrasts the non-cooperative outcomes with those of unilateral capital controls. Before the constraint starts to bind, the inflow tax $\tau_{1}<0$ imposed by the home country and the outflow $\operatorname{tax} \tau_{1}^{*}>0$ imposed by the foreign country cancel and there is no effect on the world interest rate, $R_{1}^{w}$. After the constraint starts to bind, the positive outflow taxes imposed by both the home and foreign country raise the world interest rate $R_{1}^{w}$. Furthermore, the fact that the equilibrium $\tau_{1}<\tau_{1}^{*}$ means that home country net borrowing is lower in the non-cooperative equilibrium than in the unilateral case. This reduces home consumption of the traded good and thus depresses the response of the non-traded goods price $p$, thus tightening the home country borrowing constraint. The path of $\mu$, reflecting the tightness of the borrowing constraint, is higher in the non-cooperative equilibrium than in the unilateral case.

The attempt to use capital controls for crisis management purposes is entirely undone in a non-cooperative equilibrium. The home country sets a positive capital outflow tax for a large shock, even though it is a debtor. But the foreign country also chooses a large outflow tax, which has a negative impact on the home country. As a result, in a non-cooperative equilibrium, the world interest rate is higher, home country borrowing is lower, the price of the home country non-traded good is lower, and the collateral constraint is more binding (higher $\mu$ ) than if both the home and foreign countries pursued completely open capital markets with no capital controls at all.

The asymmetric nature of the adjustment to a shock means that the home country is a net debtor and faces a domestic financial constraint. These two features compete for a capital 
control policy response. But the optimal capital tax in the foreign country is unambiguously positive. As a result, even though the two countries begin with a fully symmetric endowment process, the country receiving the large negative shock inevitably loses out when it attempts to implement a crisis management capital controls policy.

The welfare consequences for the home country in a non-cooperative equilibrium differ starkly from those under unilateral capital controls. This is shown in Figure 3, where again, welfare is measured relative to the no capital control outcome. While the two countries are of equal size and the initial equilibrium, before the shock, is fully symmetric, the noncooperative equilibrium in the case of binding collateral constraints leaves the home country much worse off, and in fact worse than the case of no capital controls at all. At the same time, when the collateral constraint binds, the foreign country may actually better off than in the Laissez Faire case.

\subsubsection{Cooperative Capital Controls}

Now suppose that the two countries cooperate to choose capital taxes to maximize overall world welfare. In the cooperative case, taxes will only be used when the borrowing constraint is binding. In Figure 1 we see that the cooperative outcome involves a home country outflow tax that is imposed as soon as the borrowing constraint binds and rises monotonically in the size of the shock. When the home constraint binds, the home country will begin to impose an outflow tax. But by raising the world interest rate, this directly benefits the foreign country. Since the home country ignores this positive spillover in a Nash equilibrium, the cooperative equilibrium calls for a higher home outflow tax than would obtain in a noncooperative equilibrium. By contrast, the foreign outflow tax imposed in a Nash equilibrium has unambiguously negative spillovers and is set to zero in the cooperative equilibrium. The higher home outflow tax in a cooperative equilibrium implies that the crisis management role of capital taxes is achieved to a greater extent with cooperation than in a non-cooperative equilibrium. 
The welfare consequences of the cooperative setting of capital controls is shown by the red line in Figure 3. Cooperative capital controls do the most to manage the binding collateral constraint in the home country, so have the greatest benefit for world welfare. But cooperative capital controls have a negative effect on the home country terms-of-trade. In Figure 3, the cooperative outcome in fact leaves the home country worse off than in the no-tax case, although still better than in the non-cooperative case. Although not shown in the Figure, it is easy to set a lump-sum transfer from foreign to home households so that both the home and foreign countries benefit from cooperative policy.

More generally, we can conclude from this and the previous two subsections that the case can be made the use of capital controls as crisis management policy in a global context only if a) there is no capital control response on the part of partner countries, or b) if there is effective policy cooperation between countries in the determination of capital controls. If neither of these two conditions are satisfied, capital controls as crisis management represent a self-defeating response to financial crises in the large open economy.

\subsubsection{Capital controls causing constraints to bind}

We observed above that the nature of the interaction between the two countries changes when financial constraints begin to bind in the home country. But in fact, the timing of the binding financial constraint itself depends upon the capital taxes chosen by the home and foreign policy-maker. Figure 5 illustrates the home and foreign best response functions where we have zoomed in towards the critical shock thresholds where the home borrowing constraint begins to bind. For regions of the shock in this neighborhood, we find that the constraint may bind under one capital tax policy scenario but not bind in another.

Figure 5 presents the home and foreign best responses when the shock size is $4.35 \%$, just below the point where the shock would start to bind in the home country in the no-tax case. The red (blue) line depicts the home (foreign) best response.

The purple line in the figure marks the combination of $\left(\tau_{1}, \tau_{1}^{*}\right)$ where the constraint is 
just binding. At any point above this line the constraint will bind and at any point below this line the constraint will not bind. The line has a slope of 1 . Holding fixed $\tau_{1}$, an increase in $\tau_{1}^{*}$ will lead the home constraint to bind more tightly. Holding fixed $\tau_{1}^{*}$, an increase in $\tau_{1}$ will relax the home country borrowing constraint.

As the shock size increases this purple line moves down, expanding the region where the home constraint binds. ${ }^{10}$ Thus, the frontier will first cross the non-cooperative equilibrium at the intersection of the two best response functions, it will then cross the unilateral equilibrium, where the home best response function crosses the x-axis. Finally it will cross the cooperative and no-tax equilibrium. The optimal cooperative $\operatorname{tax} \tau_{1}$ is marked on this plane with the red star near the origin.

This best response graph explains the path of the multiplier on the home country borrowing constraint, $\mu$, that we see in Figure 2. As the shock size increases, the constraint starts to bind first in the non-cooperative case, and then it begins to bind in the unilateral case, and finally it binds in the no-tax and cooperative cases. In the non-cooperative equilibrium, to manipulate the terms-of-trade, the foreign policymaker raises $\tau_{1}^{*}$, and this leads the home country constraint to bind at a smaller shock size. Similarly in the both the non-cooperative and unilateral cases, the desire to manipulate the terms-of-trade implies a lower value of $\tau_{1}$, and this too makes the home country constraint bind at a smaller shock size. Again, this points to a further negative aspect of non-cooperative policy-making for a country attempting to balance terms-of-trade and crisis management motives for capital controls in a depressed economy.

Recall that in the calibration we use in these numerical exercises, the shock follows a exponential distribution. The initial level of debt, $\bar{B}^{b}$, is calibrated so the probability of the constraint binding is $10 \%$. Furthermore, for ease of comparison, in this section we have assumed that when making period 0 decisions, agents assume that the period 1 policy regime

\footnotetext{
${ }^{10}$ The best response functions also shift as the shock size changes, but the movement in the best response functions is much slower than the movement in the purple frontier line as the shock size changes. The purple line moves quickly across the plane, so for all intents and purposes, we can assume that in this small region, the best response functions are fixed.
} 
will be the no-tax regime, $\tau_{1}=\tau_{1}^{*}=0$. This ensures that regardless of the period 1 tax regime, home country agents begin period 1 with the same level of precautionary savings.

In this case, the constraint starts to bind in the no-tax and cooperative regimes when the shock is around $4.6 \%$. It begins to bind in the unilateral case when the shock is around $4.4 \%$, and it begins to bind in the non-cooperative case when the shock is around $4.3 \%$. Given our assumed shock distribution, under no-tax or cooperative capital controls the probability of the constraint binding is $10 \%$, but in the unilateral case it raises to $11.1 \%$ and in the non-cooperative case it raises to $11.7 \%$.

In summary, not only does non-cooperative policy-making eliminate the possible welfare gains from the use of capital controls for crisis management, leaving the affected country worse off than if controls were unavailable, but in addition, the frequency of crises is itself higher in a non-cooperative environment.

\subsection{Period 0: Prudential policy}

We now focus on the decisions made in period 0 , before the resolution of uncertainty over the home country shock. When making decisions in period 1, both agents and policymakers take all period 0 variables as given. But the expectation of the policy regime in period 1 will affect period 0 decisions by both private agents and policy makers.

We first address the question of prudential response in period 0 by private agents, where they will determine their saving choices based on the expectation for the period 1 shock outcome as well as the policy response.

\subsubsection{Precautionary saving in period 0}

Table 1 reports the model's outcomes for precautionary savings and the resulting probability of a binding collateral constraint in period 1 under various scenarios for capital taxes in both periods.

Panel A in the table reports the probability of a binding collateral constraint, period 0 
borrower debt $B_{0}^{b}$, and period 0 net foreign assets $F_{0}$, when there are no period 0 or period 1 capital taxes. Recall that the initial stock of borrower debt $\bar{B}^{b}$ is calibrated such that the probability of a binding collateral constraint under our assumed shock process is $10 \%$. Panel B in the table presents the outcome under the three period 1 policy regimes when all period 0 variables are held constant across the three regimes. This is the scenario that was considered in the last subsection. The period 0 debt levels are the same across all 3 scenarios. The different probabilities of crises under each policy regime are those that were discussed in the last section.

Panel $\mathrm{C}$ in the table presents the outcome under the three period 1 policy regimes, but here we allow for agents to adjust their period 0 precautionary savings, anticipating the policy regime that will pertain in period 1. Agents engage in the most precautionary savings, with the highest net foreign assets $F_{0}$ and the lowest level of borrower debt $-B_{0}^{b}$, when they anticipate that period 1 policy will be non-cooperative. The next highest level of precautionary savings is when they believe period 1 policy will be unilateral. When they believe period 1 policy will be cooperative, they engage in less precautionary savings than they would have in the zero tax regime.

As a result, the probability of a binding constraint is still highest when period 1 policy is non-cooperative, but the fact that agents engage in extra precautionary savings reduces the probability from $11.7 \%$ to $11 \%$. When agents anticipate that period 1 policy will be unilateral, their extra savings reduces the probability of a crisis from $11.1 \%$ to $10.8 \%$. By contrast, when it is anticipated that period 1 policy will be cooperative, period 0 precautionary savings will actually fall, and this raises the probability of an ex post crisis from $10 \%$ to $10.6 \%$.

\subsubsection{Period 0 capital controls}

The home and foreign best response functions for setting optimal prudential policy in period 0 are presented in Figure 6. Again the home country best response is represented with the 
red line, and the foreign country is shown in the blue line. The red star near the origin represents the optimal $\left(\tau_{0}, \tau_{0}^{*}\right)$ chosen by the cooperative policymaker.

As $\tau_{0}$ increases or $\tau_{0}^{*}$ decreases, home country borrower debt in period $0,-B_{0}^{b}$, increases. A positive $\tau_{0}$ is a home country outflow tax, which will lead home savers to buy fewer foreign bonds $F_{0}$ and more domestic bonds $-B_{0}^{b}$. The 45 degree lines in the figure are iso-debt lines. The level of home country borrower debt, $-B_{0}^{b}$, is the same at each point along an iso-debt line. Iso-debt lines to the right represent a higher debt level. The best response functions and iso-debt lines in Figure 6 are calculated assuming that the period 1 policy regime is zero-tax.

Due to the precautionary savings motive, the home country will accumulate a positive stock of foreign bonds in period $0, F_{0}>0$. Thus the home country is a net saver. The home policy-maker thus has an incentive to set an outflow tax, $\tau_{0}>0$, to manipulate the terms-of-trade and raise the world interest rate in period 0. Conversely, the foreign country is a net debtor in period 0 and the foreign policy-maker has an incentive to set $\tau_{0}^{*}<0$. This terms-of-trade motive places the home country best response function to the right of the symmetric zero tax point $\tau=\tau^{*}$, and the foreign country best response function below that point. As a result, in the non-cooperative equilibrium, the home country taxes capital outflows and the foreign country taxes inflows. Referring back to equation (15), we noted that in period zero, the home country faces a trade-off between taxing capital inflows and reducing period 0 borrowing for macro-prudential reasons, as against taxing capital outflows for strategic manipulation of the terms of trade. For this calibration, we see then that the incentive to raise $\tau_{0}$ to manipulate the terms-of-trade is greater than the incentive to reduce $\tau_{0}$ for prudential reasons.

The point where the home country impulse response crosses the horizontal axis is the optimal unilateral period 0 tax set by the home country. This point lies on a higher isodebt line than the regime where there are no period 0 taxes or where the period 0 tax is cooperative. The point where the two best responses cross is the non-cooperative equilibrium 
in period 0 . This point lies on a higher iso-debt line than the unilateral regime.

The quantitative effect of these period 0 tax regimes is presented in Panel D of Table 1. As shown by the iso-debt lines in the best response figure, the level of precautionary saving is lowest when period 0 policy is non-cooperative. In the zero tax regime, the probability of a binding constraint is $10 \%$. Unilateral period 0 capital taxes reduces precautionary savings and raises this probability to $10.2 \%$. The probability increases to $10.3 \%$ when period 0 capital taxes are non-cooperative. Thus just as in the analysis of optimal period 1 capital taxes, this tension between terms-of-trade manipulation and prudential motives ensures that period 0 capital taxes are not prudential. Just as in the previous section, when policymakers set period 0 capital taxes unilaterally or non-cooperatively, they will increase the frequency of crises. But in this case, they do so by reducing period 0 precautionary savings, leading to less net foreign assets and more internal debt at the beginning of period 1 .

This is the exact counterpart to the period 1 best responses in Figure 5. When discussing period 1 policy, the terms-of-trade motive led the home country policymaker to pick a policy that made a crisis more likely (by setting $\tau_{1}<0$, and thus reducing the price of non-traded goods). In period 0 , the terms-of-trade motive leads the home country policymaker to pick a policy that makes a crisis more likely (by setting $\tau_{0}>0$, that thus leading to higher period 0 borrower debt).

Panel E Table 1 puts together the results of this section and the last section by incorporating endogenous policy choices in both period 0 and period 1 , as well as optimal period 0 precautionary saving by the private sector. Focussing first on the case of unilateral capital controls in period 0 and period 1 , we see that the period 0 capital outflow tax is three times that of Panel D, where the unilateral period 0 planner expects no tax in period 1, and likewise, the expected period 1 capital inflow tax is four times that of Panel $\mathrm{C}$, where the period 1 planner chooses a capital tax, but without any period 0 taxes. We can see the logic behind this again from equation (15). Given a period 1 inflow tax chosen by the period 1 home country to manipulate the terms of trade, the second expression in equation (15) indicates 
that the period 0 planner has an incentive to raise the period 1 outflow tax, thus reducing $F_{0}$ further than would be warranted by purely period zero terms of trade manipulation. But this then leads to a lower value of net foreign assets at the beginning of period 1 , thus exacerbating the incentive for the period 1 planner to manipulate the terms of trade. As a result we get a magnified capital outflow tax in period 0 combined with a higher capital inflow tax in period 1. The result is that the frequency of crises jumps substantially from 10 percent to 11.8 percent.

When we move from the unilateral to the non-cooperative equilibrium in both periods (the last row of Panel E), we see that the response of the foreign policy maker leads to an adjustment of period 0 outflow taxes and period 1 inflow taxes downward. Period 0 home country internal borrowing is somewhat reduced, and net foreign assets $F_{0}$ are increased. But still the probability of crises is substantially higher than the zero tax case.

In the case where policy-makers cooperative in both period 0 and period 1 , we note that, as shown above, foreign capital taxes are zero in both periods, but the home country sets an inflow tax for prudential purposes in period 0, and an expected outflow tax for crisis management purposes in period 1. This increases the net foreign assets brought into period 1 , and substantially reduces the probability of crises relative to the case of unilateral or non-cooperative policy-making.

\section{Conclusion}

This paper highlights the tension between the different motives to use capital controls in the large open economy. On one hand, the policymaker in the large open economy desires to use capital controls for terms-of-trade manipulation, on the other hand they may desire to use

capital controls for crisis management. In the first they exploit the fact that by changing capital taxes they can manipulate the world interest rate, in the second they exploit the fact that by changing capital taxes they can manipulate the domestic price of non-traded goods. 
The fact that the policy maker in the large open economy can use capital controls to manipulate the world interest rate provides the violation of Korinek's "first welfare theorem for open economies" (Korinek 2017), and ensures a role for international cooperation. The results in the capital controls literature concerning optimal macro-prudential capital controls is derived from small open economy models. Our results show that those same type of unilateral capital controls would be ineffective for macro-prudential policy in the large open economy. And once we factor in the possibility of strategic interactions and capital controls imposed by the foreign country, non-cooperative capital controls are not only ineffective, they are harmful to the country in crisis. 


\section{References}

Benigno, G., Chen, H., Otrok, C., Rebucci, A., Young, E. R., 2013. Financial crises and macro-prudential policies. Journal of International Economics 89, 453-470.

https://doi.org/10.1016/j.jinteco.2012.06.002

Benigno, G., Chen, H., Otrok, C., Rebucci, A., Young, E. R., 2016. Optimal capital controls and real exchange rate policies: A pecuniary externality perspective. Journal of Monetary Economics 84, 147-165.

https://doi.org/10.1016/j.jmoneco.2016.10.004

Bianchi, J., 2011. Overborrowing and systemic externalities in the business cycle. American Economic Review 101 (7), 3400-3426.

https://doi.org/10.1257/aer.101.7.3400

Bianchi, J., Mendoza, E. G., 2018. Optimal time-consistent macroprudential policy. Journal of Political Economy 126 (2), 588-634.

https://doi.org/10.1086/696280

Costinot, A., Lorenzoni, G., Werning, I., 2014. A theory of capital controls as dynamic terms-of-trade manipulation. Journal of Political Economy 122 (1), 77-128.

https://doi.org/10.1086/674425

Davila, E., Korinek, A., 2017. Pecuniary externalities in economies with financial frictions. The Review of Economic Studies 85 (1), 352-395.

https://doi.org/10.1093/restud/rdx010

De Paoli, B., Lipinska, A., February 2013. Capital controls: A normative analysis. FRBNY Staff Report No. 600.

https://dx.doi.org/10.2139/ssrn. 2213321

Devereux, M. B., Young, E. R., Yu, C., 2018. Capital controls and monetary policy in sudden-stop economies. Journal of Monetary Economics.

https://doi.org/10.1016/j.jmoneco.2018.07.016

Edwards, S., 1999. How effective are capital controls? Journal of Economic Perspectives $13(4), 65-84$.

https://doi.org/10.1257/jep.13.4.65

Farhi, E., Werning, I., 2014. Dilemma not trilemma?; capital controls and exchange rates with volatile capital flows. IMF Economic Review 62 (4), 569-605.

https://doi.org/10.1057/imfer.2014.25

Farhi, E., Werning, I., 2016. A theory of macroprudential policies in the presence of nominal rigidities. Econometrica 84 (5), 1645-1704.

https://doi.org/10.3982/ecta11883 
Heathcote, J., Perri, F., 2016. On the desirability of capital controls. IMF Economic Review 64 (1), 75-102.

https://doi.org/10.1057/imfer.2016.7

International Monetary Fund, November 2012. The liberalization and management of capital flows: An institutional view.

Jeanne, O., Korinek, A., 2010. Excessive volatility in capital flows: A pigouvian taxation approach. American Economic Review (Papers and Proceedings) 100 (2), 403-407. https://doi.org/10.1257/aer.100.2.403

Jeanne, O., Korinek, A., January 2013. Macroprudential regulation versus mopping up after the crash. NBER Working Paper No. 18675.

https://doi.org/10.3386/w18675

Jeanne, O., Korinek, A., 2018. Managing credit booms and busts: A pigouvian taxation approach. Journal of Monetary Economics. https://doi.org/10.1016/j.jmoneco.2018.12.005

Korinek, A., January 2017. Currency wars or efficient spillovers. mimeo. https://doi.org/10.3386/w23004

Korinek, A., 2018. Regulating capital flows to emerging markets: An externality view. Journal of International Economics 111, 61-80. https://doi.org/10.1016/j.jinteco.2017.12.005

Korinek, A., Sandri, D., 2016. Capital controls or macroprudential regulation? Journal of International Economics 99, S27-S42. https://doi.org/10.1016/j.jinteco.2016.02.001

Korinek, A., Simsek, A., 2016. Liquidity trap and excessive leverage. American Economic Review 106 (3), 699-738. https://doi.org/10.1257/aer.20140289

Lorenzoni, G., 2008. Inefficient credit booms. The Review of Economic Studies 75 (3), 809833.

https://doi.org/10.3386/w13639

Ma, C., Rebucci, A., 2019. Capital controls: A brief survey of the new literature. mimeo.

Magud, N. E., Reinhart, C. M., Rogoff, K. S., 2018. Capital controls: myth and reality. Annals of Economics and Finance 19 (1), 1-47. https://doi.org/10.3386/w16805

Mendoza, E. G., 2010. Sudden stops, financial crises, and leverage. American Economic Review 100 (5), 1941-1966. https://doi.org/10.1257/aer.100.5.1941 
Schmitt-Grohe, S., Uribe, M., 2016. Downward nominal wage rigidity, currency pegs, and involuntary unemployment. Journal of Political Economy 124 (5), 1466-1514.

https://doi.org/10.1086/688175 


\section{A Appendix}

In this appendix we first present the full list of the 40 variables and equations in the model. We then solve the planner's problem for the optimal $\tau_{1}$ or $\tau_{0}$.

\section{A.1 Full list of model variables and equations}

This has been updated with the addition of period 0

There are 40 variables in the model. 26 in periods 1 and $2: c_{2, X}^{b}, c_{1, X}^{b}, c_{1, Y}^{b}, c_{2, X}^{s}, c_{1, X}^{s}$, $c_{1, Y}^{s}, c_{2, X}^{*}, c_{1, X}^{*}, c_{1, Y}^{*}, R_{1}, R_{1}^{*}, B_{1}^{b}, B_{1}^{s}, B_{1}^{*}, F_{1}, F_{1}^{*}, \lambda_{1}^{b}, \lambda_{2}^{b}, \lambda_{1}^{s}, \lambda_{2}^{s}, \lambda_{1}^{*}, \lambda_{2}^{*}, \mu, p, p^{*}, T, R_{1}^{W}$ and 14 in period $0: c_{0, X}^{b}, c_{0, X}^{s}, c_{0, X}^{*}, R_{0}, R_{0}^{*}, B_{0}^{b}, B_{0}^{s}, B_{0}^{*}, F_{0}, F_{0}^{*}, \lambda_{0}^{b}, \lambda_{0}^{s}, \lambda_{0}^{*}, R_{0}^{W}$

The 40 model equations are given by:

$$
\begin{gathered}
c_{2, X}^{b}:\left(c_{2, X}^{b}\right)^{-\sigma}=\lambda_{2}^{b} \\
c_{1, X}^{b}:\left(\frac{1}{\alpha^{\alpha}(1-\alpha)^{1-\alpha}}\left(c_{1, X}^{b}\right)^{\alpha}\left(c_{1, Y}^{b}\right)^{1-\alpha}\right)^{1-\sigma} \alpha\left(c_{1, X}^{b}\right)^{-1}=\lambda_{1}^{b} \\
c_{1, Y}^{b}:\left(\frac{1}{\alpha^{\alpha}(1-\alpha)^{1-\alpha}}\left(c_{1, X}^{b}\right)^{\alpha}\left(c_{1, Y}^{b}\right)^{1-\alpha}\right)^{1-\sigma}(1-\alpha)\left(c_{1, Y}^{b}\right)^{-1}=p \lambda_{1}^{b} \\
c_{2, X}^{s}:\left(c_{2, X}^{s}\right)^{-\sigma}=\lambda_{2}^{s} \\
c_{1, X}^{s}:\left(\frac{1}{\alpha^{\alpha}(1-\alpha)^{1-\alpha}}\left(c_{1, X}^{s}\right)^{\alpha}\left(c_{1, Y}^{s}\right)^{1-\alpha}\right)^{1-\sigma} \alpha\left(c_{1, X}^{s}\right)^{-1}=\lambda_{1}^{s} \\
c_{2, X}^{*}:\left(c_{2, X}^{*}\right)^{-\sigma}=\lambda_{2}^{*} \\
c_{1, Y}^{s}:\left(\frac{1}{\alpha^{\alpha}(1-\alpha)^{1-\alpha}}\left(c_{1, X}^{s}\right)^{\alpha}\left(c_{1, Y}^{s}\right)^{1-\alpha}\right)^{1-\sigma}(1-\alpha)\left(c_{1, Y}^{s}\right)^{-1}=p \lambda_{1}^{s}
\end{gathered}
$$




$$
\begin{gathered}
c_{1, X}^{*}:\left(\frac{1}{\alpha^{\alpha}(1-\alpha)^{1-\alpha}}\left(c_{1, X}^{*}\right)^{\alpha}\left(c_{1, Y}^{*}\right)^{1-\alpha}\right)^{1-\sigma} \alpha\left(c_{1, X}^{*}\right)^{-1}=\lambda_{1}^{*} \\
c_{1, Y}^{*}:\left(\frac{1}{\alpha^{\alpha}(1-\alpha)^{1-\alpha}}\left(c_{1, X}^{*}\right)^{\alpha}\left(c_{1, Y}^{*}\right)^{1-\alpha}\right)^{1-\sigma}(1-\alpha)\left(c_{1, Y}^{*}\right)^{-1}=p \lambda_{1}^{*}
\end{gathered}
$$$$
R_{1}: B_{1}^{b}=B_{1}^{s}
$$$$
R_{1}^{*}: B_{1}^{*}=0
$$$$
B_{1}^{b}: \frac{\lambda_{1}^{b}-\mu}{R_{1}}=\beta \lambda_{2}^{b}
$$$$
B_{1}^{s}: \frac{\lambda_{1}^{s}}{R_{1}}=\beta \lambda_{2}^{s}
$$$$
B_{1}^{*}: \frac{\lambda_{1}^{*}}{R_{1}^{*}}=\beta \lambda_{2}^{*}
$$

$$
F_{1}: \frac{\lambda_{1}^{s}\left(1+\tau_{1}\right)}{R_{1}^{W}}=\beta \lambda_{2}^{s}
$$

$$
F_{1}^{*}: \frac{\lambda_{1}^{*}\left(1+\tau_{1}^{*}\right)}{R_{1}^{W}}=\beta \lambda_{2}^{*}
$$$$
\lambda_{1}^{b}: c_{1, X}^{b}+p c_{1, Y}^{b}+\frac{B_{1}^{b}}{R_{1}}=x_{1}^{b}+p y_{1}^{b}+B_{0}^{b}
$$

$$
\lambda_{2}^{b}: c_{2, X}^{b}=x_{2}^{b}+B_{1}^{b}+T
$$




$$
\begin{gathered}
\lambda_{1}^{s}: c_{1, X}^{s}+p c_{1, Y}^{s}+\frac{B_{1}^{s}}{R_{1}}+\left(1+\tau_{1}\right) \frac{F_{1}}{R_{1}^{W}}+\Gamma_{1}=x_{1}^{s}+p y_{1}^{s}+B_{0}^{s}+F_{0} \\
\lambda_{2}^{s}: c_{2, X}^{s}=x_{2}^{s}+B_{1}^{s}+F_{1}-T \\
\lambda_{1}^{*}: c_{1, X}^{*}+p^{*} c_{1, Y}^{*}+\frac{B_{1}^{*}}{R_{1}^{*}}+\left(1+\tau_{1}^{*}\right) \frac{F_{1}^{*}}{R_{1}^{W}}+\Gamma_{1}^{*}=x_{1}^{*}+p^{*} y_{1}^{*}+B_{0}^{*}+F_{0}^{*} \\
\lambda_{2}^{*}: c_{2, X}^{*}=x_{2}^{*}+B_{1}^{*}+F_{1}^{*} \\
\mu:-\frac{B_{1}^{b}}{R_{1}}=\kappa\left(x_{1}^{b}+p y_{1}^{b}\right) \text { or } \mu=0 \\
R_{1}^{W}: F_{1}=F_{1}^{*} \\
p: c_{1, Y}^{b}+c_{1, Y}^{s}=y_{1}^{s}+y_{1}^{b} \\
p^{*}: c_{1, Y}^{*}=y_{1}^{*}
\end{gathered}
$$

and

$$
\begin{gathered}
c_{0, X}^{b}:\left(c_{0, X}^{b}\right)^{-\sigma}=\lambda_{0}^{b} \\
c_{0, X}^{s}:\left(c_{0, X}^{s}\right)^{-\sigma}=\lambda_{0}^{s}
\end{gathered}
$$




$$
\begin{gathered}
c_{0, X}^{*}:\left(c_{0, X}^{*}\right)^{-\sigma}=\lambda_{0}^{*} \\
R_{0}: B_{0}^{b}=B_{0}^{s} \\
R_{0}^{*}: B_{0}^{*}=0 \\
\lambda_{0}^{b}: \frac{\lambda_{0}^{b}}{R_{0}}=\beta E\left(\lambda_{1}^{b}\right) \\
\lambda_{0}^{*}: c_{0, X}^{*}+\frac{B_{0}^{*}}{R_{0}^{*}}+\left(1+\tau_{0}^{*}\right) \frac{F_{0}}{R_{0}^{W}}+\Gamma_{0}^{*}=x_{0}^{*} \\
B_{0}^{s}=\beta E\left(\lambda_{1}^{s}\right) \\
\lambda_{0}^{s}+\left(1+\tau_{0}^{b}\right) \frac{F_{0}}{R_{0}^{W}}+\Gamma_{0}=x_{0}^{s}+\bar{B}^{s} \\
B_{0}^{*}: \frac{\lambda_{0}^{*}}{R_{0}^{*}}=\beta E\left(\lambda_{1}^{*}\right) \\
F_{0}: \frac{\lambda_{0}^{s}\left(1+\tau_{0}\right)}{R_{0}^{W}}=\beta E\left(\lambda_{1}^{s}\right) \\
F_{0}^{*}: \frac{\lambda_{0}^{*}\left(1+\tau_{0}^{*}\right)}{R_{0}^{W}}=\beta E\left(\lambda_{1}^{*}\right)
\end{gathered}
$$




$$
R_{0}^{W}: F_{0}=F_{0}^{*}
$$

\section{A.2 Planner's problem}

The home country policymaker will choose $\tau_{t}$ to maximize the sum of home saver and borrower welfare subject to the saver and borrower budget constraints in each period and the borrower borrowing constraint. The Lagrangian is given by (where for brevity we have gone ahead and made the substitution based on the domestic bond market clearing $B_{t}^{h}=$ $B_{t}^{b, h}=-B_{t}^{s, h}$ and $\bar{B}^{h}=\bar{B}^{b, h}=-\bar{B}^{s, h}$ for $\left.t=0,1\right)$ :

$$
\begin{aligned}
W= & u\left(c_{0, X}^{s}\right)+\beta u\left(c_{1, X}^{s}, c_{1, Y}^{s}\right)+\beta^{2} u\left(c_{2, X}^{s}\right)+u\left(c_{0, X}^{b}\right)+\beta u\left(c_{1, X}^{b}, c_{1, Y}^{b}\right)+\beta^{2} u\left(c_{2, X}^{b}\right) \\
& -\lambda_{0}^{b}\left(c_{0, X}^{b}+\frac{B_{0}}{R_{0}}-x_{0}^{b}-\bar{B}\right) \\
& -\beta \lambda_{1}^{b}\left(c_{1, X}^{b}+p c_{1, Y}^{b}+\frac{B_{1}}{R_{1}}-x_{1}^{b}-p y_{1}^{b}-B_{0}\right) \\
& -\beta^{2} \lambda_{2}^{b}\left(c_{2, X}^{b}-x_{2}^{b}-B_{1}-T\right) \\
& -\lambda_{0}^{s}\left(c_{0, X}^{s}-\frac{B_{0}}{R_{0}}+\frac{\left(1+\tau_{0}\right) F_{0}}{R_{0}^{W}}+\Gamma_{0}-x_{0}^{s}+\bar{B}\right) \\
& -\beta \lambda_{1}^{s}\left(c_{1, X}^{s}+p c_{1, Y}^{s}-\frac{B_{1}}{R_{1}}+\frac{\left(1+\tau_{1}\right) F_{1}}{R_{1}^{W}}+\Gamma_{1}-x_{1}^{s}-p y_{1}^{s}+B_{0}-F_{0}\right) \\
& -\beta^{2} \lambda_{2}^{s}\left(c_{2, X}^{s}-x_{2}^{s}+B_{1}-F_{1}+T\right) \\
& -\mu\left(-\frac{B_{1}}{R_{1}}-\kappa\left(x_{1}^{b}+p y_{1}^{b}\right)\right)
\end{aligned}
$$

We can go ahead and make the substitution $\Gamma_{t}=-\frac{\tau_{t} F_{t}}{R_{t}^{W}}$, since the planner internalizes the fact that tax revenues are rebated back to savers lump sum.

\section{A.2.1 Choice of ex-post capital controls $\tau_{1}$}

When taking the derivative $\frac{d W}{d \tau_{1}}$, since the choice of $\tau_{1}$ is made in period 1 , the planner will take all period 0 variables as given: $c_{0, X}^{b}, c_{0, X}^{s}, c_{0, X}^{*}, R_{0}, R_{0}^{*}, B_{0}^{b}, B_{0}^{s}, B_{0}^{*}, F_{0}, F_{0}^{*}, \lambda_{0}^{b}, \lambda_{0}^{s}, \lambda_{0}^{*}$, 
$R_{0}^{W}$. Terms involving the derivatives of $c_{1, X}^{s}, c_{1, Y}^{s}, c_{2, X}^{s}, c_{1, X}^{b}, c_{1, Y}^{b}, c_{2, X}^{b}, B_{1}$ will cancel since households are already optimizing with respect to these variables. This leaves the derivatives of $p, F_{1}, R_{1}, R_{1}^{W}$ since those variables are not internalized by households, or they are not fully internalized by households (in the case of $F_{1}$, households do not internalize the rebating of the tax revenue)

$$
\begin{aligned}
\frac{d W}{d \tau_{1}}= & \left(-\lambda_{1}^{b}\left(c_{1, Y}^{b}-y_{1}^{b}\right)-\lambda_{1}^{s}\left(c_{1, Y}^{s}-y_{1}^{s}\right)\right) \frac{d p}{d \tau_{1}} \\
& +\left(\lambda_{1}^{b}-\lambda_{1}^{s}\right) \frac{B_{1}}{\left(R_{1}\right)^{2}} \frac{d R_{1}}{d \tau_{1}}+\left(-\lambda_{1}^{s} \frac{1}{R_{1}^{w}}+\beta \lambda_{2}^{s}\right) \frac{d F_{1}}{d \tau_{1}} \\
& +\lambda_{1}^{s} \frac{F_{1}}{\left(R_{1}^{w}\right)^{2}} \frac{d R_{1}^{w}}{d \tau_{1}}-\mu \frac{B_{1}}{\left(R_{1}\right)^{2}} \frac{d R_{1}}{d \tau_{1}} \\
& +\kappa \mu y_{1}^{b} \frac{d p}{d \tau_{1}}
\end{aligned}
$$

And after some rearranging this becomes:

$$
\begin{aligned}
\frac{d W}{d \tau_{1}}= & \beta\left(-R_{1} \lambda_{2}^{b}\left(c_{1, Y}^{b}-y_{1}^{b}\right)-R_{1} \lambda_{2}^{s}\left(c_{1, Y}^{s}-y_{1}^{s}\right)\right) \frac{d p}{d \tau_{1}} \\
& +\beta\left(\lambda_{2}^{b}-\lambda_{2}^{s}\right) \frac{B_{1}}{R_{1}} \frac{d R_{1}}{d \tau_{1}} \\
& +\left(-\lambda_{1}^{s} \frac{1}{R_{1}^{w}}+\beta \lambda_{2}^{s}\right) \frac{d F_{1}}{d \tau_{1}}+\lambda_{1}^{s} \frac{F_{1}}{\left(R_{1}^{w}\right)^{2}} \frac{d R_{1}^{w}}{d \tau_{1}} \\
& +\left(\kappa y_{1}^{b}-\left(c_{1, Y}^{b}-y_{1}^{b}\right)\right) \mu \frac{d p}{d \tau_{1}}
\end{aligned}
$$

The first two lines in this derivative represent the planner's use of $\tau_{1}$ for domestic redistribution, either by changing $p$, and thus affecting saver and borrower welfare due to differences in consumption and endowments of the non-traded good, $c_{1, Y}^{b}-y_{1}^{b}$ and $c_{1, Y}^{s}-y_{1}^{s}$. Or by changing $R_{1}$ and thus affecting saver and borrower welfare given that borrowers hold a stock of bonds $B_{1}<0$. The use of the transfer $T$ is meant to eliminate the planner's motive to use $\tau_{1}$ for domestic redistribution, where $T$ is set such that $\lambda_{2}^{b}=\lambda_{2}^{s}$. Thus the transfer 
will eliminate the first two lines of this derivative.

The third line of this derivative represents the planner's use of $\tau_{1}$ for terms-of-trade manipulation.

And finally the fourth line in the derivative represents the macroprudential motive for the use of $\tau_{1}$. Note that this motive is only relevant when the constraint is binding and thus $\mu>0$. By increasing $\tau_{1}$ the planner will reduce exports of the traded good in the first period and thus increase the relative price of the non-traded good, $\frac{d p}{d \tau_{1}}>0$. This increase in the relative price of the non-traded good will lead to a loosening of the home country borrowing constraint by increasing the value of the borrower's collateral, $\kappa y_{1}^{b}$. But at the same time the increase in $p$ will either tighten or loosen the borrowing constraint depending on whether the borrower consumes more or less of the non-traded good than their endowment, $c_{1, Y}^{b}-y_{1}^{b}$.

Since the first two lines in this derivative cancel out due to the transfer, the maximization condition reduces to (after factoring in the equilibrium conditions $R_{1}=\frac{R_{1}^{w}}{1+\tau}$ and the saver's first order condition with respect to $\left.F_{1}\right)$ :

$$
\frac{d W}{d \tau_{1}}=\frac{\lambda_{1}^{s}}{R_{1}^{w}}\left(\tau_{1} \frac{d F_{1}}{d \tau_{1}}+\frac{F_{1}}{R_{1}^{w}} \frac{d R_{1}^{w}}{d \tau_{1}}\right)+\left(\kappa y_{1}^{b}-\left(c_{1, Y}^{b}-y_{1}^{b}\right)\right) \mu \frac{d p}{d \tau_{1}}=0
$$

\section{A.2.2 Choice of ex-ante capital controls $\tau_{0}$}

When taking the derivative $\frac{d W}{d \tau_{0}}$, the derivatives with respect to $c_{0, X}^{b}, c_{0, X}^{s}, B_{0}^{b}, B_{0}^{s}, c_{1, X}^{s}, c_{1, Y}^{s}$, $c_{2, X}^{s}, c_{1, X}^{b}, c_{1, Y}^{b}, c_{2, X}^{b}, B_{1}$ will cancel since households are optimizing with respect to these variables. This leaves the derivatives of $p, F_{1}, R_{1}, R_{1}^{W}, R_{0}, F_{0}, R_{0}^{W}$ since households do not internalize these variables, or in the case of $F_{0}$ and $F_{1}$, do not fully internalize (since they do not internalize the rebate of the tax revenue): (all period 1 and 2 variables are expected values since this is taken before the shock in period 1) 


$$
\begin{aligned}
\frac{d W}{d \tau_{0}}= & \left(-\lambda_{1}^{b}\left(c_{1, Y}^{b}-y_{1}^{b}\right)-\lambda_{1}^{s}\left(c_{1, Y}^{s}-y_{1}^{s}\right)\right) \frac{d p}{d \tau_{0}} \\
& +\left(\lambda_{1}^{b}-\lambda_{1}^{s}\right) \frac{B_{1}}{\left(R_{1}\right)^{2}} \frac{d R_{1}}{d \tau_{0}}+\left(-\lambda_{1}^{s} \frac{1}{R_{1}^{w}}+\beta \lambda_{2}^{s}\right) \frac{d F_{1}}{d \tau_{0}} \\
& +\lambda_{1}^{s} \frac{F_{1}}{\left(R_{1}^{w}\right)^{2}} \frac{d R_{1}^{w}}{d \tau_{0}}-\mu \frac{B_{1}}{\left(R_{1}\right)^{2}} \frac{d R_{1}}{d \tau_{0}} \\
& +\kappa \mu y_{1}^{b} \frac{d p}{d \tau_{0}} \\
& +\left(\lambda_{0}^{b}-\lambda_{0}^{s}\right) \frac{B_{0}}{\left(R_{0}\right)^{2}} \frac{d R_{0}}{d \tau_{0}}+\left(-\lambda_{0}^{s} \frac{1}{R_{0}^{w}}+\beta \lambda_{1}^{s}\right) \frac{d F_{0}}{d \tau_{0}} \\
& +\lambda_{0}^{s} \frac{F_{0}}{\left(R_{0}^{w}\right)^{2}} \frac{d R_{0}^{w}}{d \tau_{0}}
\end{aligned}
$$

And after some rearranging this becomes:

$$
\begin{aligned}
\frac{d W}{d \tau_{0}}= & \beta\left(-R_{1} \lambda_{2}^{b}\left(c_{1, Y}^{b}-y_{1}^{b}\right)-R_{1} \lambda_{2}^{s}\left(c_{1, Y}^{s}-y_{1}^{s}\right)\right) \frac{d p}{d \tau_{0}} \\
& +\beta\left(\lambda_{2}^{b}-\lambda_{2}^{s}\right) \frac{B_{1}}{R_{1}} \frac{d R_{1}}{d \tau_{0}} \\
& +\left(-\lambda_{1}^{s} \frac{1}{R_{1}^{w}}+\beta \lambda_{2}^{s}\right) \frac{d F_{1}}{d \tau_{0}}+\lambda_{1}^{s} \frac{F_{1}}{\left(R_{1}^{w}\right)^{2}} \frac{d R_{1}^{w}}{d \tau_{0}} \\
& +\left(\kappa y_{1}^{b}-\left(c_{1, Y}^{b}-y_{1}^{b}\right)\right) \mu \frac{d p}{d \tau_{0}} \\
& +\beta^{2} R_{1}\left(\lambda_{2}^{b}-\lambda_{2}^{s}\right) \frac{B_{0}}{R_{0}} \frac{d R_{0}}{d \tau_{0}}+\beta \mu \frac{B_{0}}{R_{0}} \frac{d R_{0}}{d \tau_{0}} \\
& +\left(-\lambda_{0}^{s} \frac{1}{R_{0}^{w}}+\beta \lambda_{1}^{s}\right) \frac{d F_{0}}{d \tau_{0}}+\lambda_{0}^{s} \frac{F_{0}}{\left(R_{0}^{w}\right)^{2}} \frac{d R_{0}^{w}}{d \tau_{0}}
\end{aligned}
$$

Where we are making the substitution 


$$
\begin{aligned}
\left(\lambda_{0}^{b}-\lambda_{0}^{s}\right) \frac{B_{0}}{\left(R_{0}\right)^{2}} \frac{d R_{0}}{d \tau_{0}} & =\beta\left(\lambda_{1}^{b}-\lambda_{1}^{s}\right) \frac{B_{0}}{R_{0}} \frac{d R_{0}}{d \tau_{0}} \\
& =\beta\left(\lambda_{1}^{b}-\lambda_{1}^{s}\right) \frac{B_{0}}{R_{0}} \frac{d R_{0}}{d \tau_{0}}-\beta \mu \frac{B_{0}}{R_{0}} \frac{d R_{0}}{d \tau_{0}}+\beta \mu \frac{B_{0}}{R_{0}} \frac{d R_{0}}{d \tau_{0}} \\
& =\beta\left(\lambda_{1}^{b}-\mu-\lambda_{1}^{s}\right) \frac{B_{0}}{R_{0}} \frac{d R_{0}}{d \tau_{0}}+\beta \mu \frac{B_{0}}{R_{0}} \frac{d R_{0}}{d \tau_{0}} \\
& =\beta^{2} R_{1}\left(\lambda_{2}^{b}-\lambda_{2}^{s}\right) \frac{B_{0}}{R_{0}} \frac{d R_{0}}{d \tau_{0}}+\beta \mu \frac{B_{0}}{R_{0}} \frac{d R_{0}}{d \tau_{0}}
\end{aligned}
$$

Using the fact that $\lambda_{2}^{b}=\lambda_{2}^{s}$, the expression for $\frac{d W}{d \tau_{0}}$ reduces to:

$$
\frac{d W}{d \tau_{0}}=\frac{\lambda_{1}^{s}}{R_{1}^{w}}\left(\tau_{1} \frac{d F_{1}}{d \tau_{0}}+\frac{F_{1}}{R_{1}^{w}} \frac{d R_{1}^{w}}{d \tau_{0}}\right)+\left(\kappa y_{1}^{b}-\left(c_{1, Y}^{b}-y_{1}^{b}\right)\right) \mu \frac{d p}{d \tau_{0}}+\beta \mu \frac{B_{0}}{R_{0}} \frac{d R_{0}}{d \tau_{0}}+\frac{\lambda_{0}^{s}}{R_{0}^{w}}\left(\tau_{0} \frac{d F_{0}}{d \tau_{0}}+\frac{F_{0}}{R_{0}^{w}} \frac{d R_{0}^{w}}{d \tau_{0}}\right)=0
$$

So the optimal $\tau_{0}$ is:

$$
\tau_{0}=-\frac{F_{0}}{R_{0}^{w}} \frac{d R_{0}^{w}}{d F_{0}}-\frac{R_{0}^{w}}{\lambda_{0}^{s}} \frac{\lambda_{1}^{s}}{R_{1}^{w}}\left(\tau_{1} \frac{d F_{1}}{d F_{0}}+\frac{F_{1}}{R_{1}^{w}} \frac{d R_{1}^{w}}{d F_{0}}\right)-\left(\kappa y_{1}^{b}-\left(c_{1, Y}^{b}-y_{1}^{b}\right)\right) \mu \frac{d p}{d F_{0}}-\beta \mu \frac{B_{0}}{R_{0}} \frac{d R_{0}}{d F_{0}}
$$

The first order condition of world welfare with respect to $\tau_{0}$ is:

$$
\begin{aligned}
\frac{d W^{w}}{d \tau_{0}}= & \beta\left(-R_{1} \lambda_{2}^{b}\left(c_{1, Y}^{b}-y_{1}^{b}\right)-R_{1} \lambda_{2}^{s}\left(c_{1, Y}^{s}-y_{1}^{s}\right)\right) \frac{d p}{d \tau_{0}}+\lambda_{1}^{*}\left(c_{1, Y}^{*}-y_{1}^{*}\right) \frac{d p}{d \tau_{0}} \\
& +\beta\left(\lambda_{2}^{b}-\lambda_{2}^{s}\right) \frac{B_{1}}{R_{1}} \frac{d R_{1}}{d \tau_{0}}+\lambda_{1}^{*} \frac{B_{1}^{*}}{R_{1}^{*}} \frac{d R_{1}^{*}}{d \tau_{0}} \\
& +\left(-\lambda_{1}^{s} \frac{1}{R_{1}^{w}}+\beta \lambda_{2}^{s}\right) \frac{d F_{1}}{d \tau_{0}}+\left(-\lambda_{1}^{*} \frac{1}{R_{1}^{w}}+\beta \lambda_{2}^{*}\right) \frac{d F_{1}^{*}}{d \tau_{0}}+\lambda_{1}^{s} \frac{F_{1}}{\left(R_{1}^{w}\right)^{2}} \frac{d R_{1}^{w}}{d \tau_{0}}+\lambda_{1}^{*} \frac{F_{1}^{*}}{\left(R_{1}^{w}\right)^{2}} \frac{d R_{1}^{w}}{d \tau_{0}} \\
& +\left(\kappa y_{1}^{b}-\left(c_{1, Y}^{b}-y_{1}^{b}\right)\right) \mu \frac{d p}{d \tau_{0}} \\
& +\beta^{2} R_{1}\left(\lambda_{2}^{b}-\lambda_{2}^{s}\right) \frac{B_{0}}{R_{0}} \frac{d R_{0}}{d \tau_{0}}+\beta \mu \frac{B_{0}}{R_{0}} \frac{d R_{0}}{d \tau_{0}} \\
& +\left(-\lambda_{0}^{s} \frac{1}{R_{0}^{w}}+\beta \lambda_{1}^{s}\right) \frac{d F_{0}}{d \tau_{0}}+\left(-\lambda_{0}^{*} \frac{1}{R_{0}^{w}}+\beta \lambda_{1}^{*}\right) \frac{d F_{0}^{*}}{d \tau_{0}}+\lambda_{0}^{s} \frac{F_{0}}{\left(R_{0}^{w}\right)^{2}} \frac{d R_{0}^{w}}{d \tau_{0}}+\lambda_{0}^{*} \frac{F_{0}^{*}}{\left(R_{0}^{w}\right)^{2}} \frac{d R_{0}^{w}}{d \tau_{0}}
\end{aligned}
$$


which simplifies to:

$$
\begin{aligned}
\frac{d W^{w}}{d \tau_{0}}= & \frac{\lambda_{1}^{s}}{R_{1}^{w}} \tau_{1} \frac{d F_{1}}{d \tau_{0}}+\lambda_{1}^{s} \frac{F_{1}}{\left(R_{1}^{w}\right)^{2}} \frac{d R_{1}^{w}}{d \tau_{0}}+\lambda_{1}^{*} \frac{F_{1}^{*}}{\left(R_{1}^{w}\right)^{2}} \frac{d R_{1}^{w}}{d \tau_{0}} \\
& +\left(\kappa y_{1}^{b}-\left(c_{1, Y}^{b}-y_{1}^{b}\right)\right) \mu \frac{d p}{d \tau_{0}} \\
& +\beta \mu \frac{B_{0}}{R_{0}} \frac{d R_{0}}{d \tau_{0}} \\
& +\left(-\lambda_{0}^{s} \frac{1}{R_{0}^{w}}+\beta \lambda_{1}^{s}\right) \frac{d F_{0}}{d \tau_{0}}+\lambda_{0}^{s} \frac{F_{0}}{\left(R_{0}^{w}\right)^{2}} \frac{d R_{0}^{w}}{d \tau_{0}}+\lambda_{0}^{*} \frac{F_{0}^{*}}{\left(R_{0}^{w}\right)^{2}} \frac{d R_{0}^{w}}{d \tau_{0}}
\end{aligned}
$$


Table 1: The probability of a binding constraint in period 1 and period 0 debt levels under different capital control regimes.

\begin{tabular}{|c|c|c|c|c|c|c|c|}
\hline & $\bar{\tau} \tau_{0}$ & $\bar{\tau}_{0}^{*}$ & $E\left(\tau_{1}\right)$ & $E\left(\tau_{1}^{*}\right)$ & Crisis Prob. & 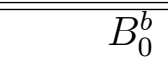 & 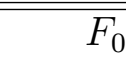 \\
\hline Zero tax & 0.0000 & 0.0000 & 0.0000 & 0.0000 & 10.0 & -0.4810 & 0.0021 \\
\hline Optimal Period 1 Tax & & & & & & & \\
\hline (hold per 0 variables fixed) & & & & & & & \\
\hline Unilateral $\tau_{1}$ & 0.000 & 0.000 & -0.162 & 0.000 & 11.1 & -0.4810 & 0.0021 \\
\hline Cooperative $\tau_{1}$ & 0.000 & 0.000 & 0.124 & 0.000 & 10.0 & -0.4810 & 0.0021 \\
\hline Non-cooperative $\tau_{1}$ & 0.000 & 0.000 & -0.066 & 0.243 & 11.7 & -0.4810 & 0.0021 \\
\hline \multirow{2}{*}{\multicolumn{8}{|c|}{$\begin{array}{r}\text { Optimal Period } 1 \text { Tax } \\
\text { (precautionary affect per } 0 \text { variables) }\end{array}$}} \\
\hline & & & & & & & \\
\hline Unilateral $\tau_{1}$ & 0.000 & 0.000 & -0.095 & 0.000 & 10.8 & -0.4808 & 0.0026 \\
\hline Cooperative $\tau_{1}$ & 0.000 & 0.000 & 0.132 & 0.000 & 10.6 & -0.4814 & 0.0015 \\
\hline Non-cooperative $\tau_{1}$ & 0.000 & 0.000 & 0.009 & 0.154 & 11.0 & -0.4806 & 0.0028 \\
\hline \multicolumn{8}{|l|}{$\begin{array}{r}\text { Optimal Period } 0 \text { Tax } \\
\text { (assume Per } 1 \text { is zero tax) }\end{array}$} \\
\hline Unilateral $\tau_{0}$ & 0.062 & 0.000 & 0.000 & 0.000 & 10.2 & -0.4812 & 0.0015 \\
\hline Cooperative $\tau_{0}$ & 0.001 & 0.000 & 0.000 & 0.000 & 10.0 & -0.4810 & 0.0021 \\
\hline Non-cooperative $\tau_{0}$ & 0.052 & -0.022 & 0.000 & 0.000 & 10.3 & -0.4812 & 0.0014 \\
\hline \multicolumn{8}{|l|}{$\begin{array}{l}\text { Optimal Period } 0 \text { and } 1 \text { Tax } \\
\text { (tax in both periods) }\end{array}$} \\
\hline Unilateral $\tau_{0}$ and $\tau_{1}$ & 0.168 & 0.000 & -0.358 & 0.000 & 11.8 & -0.4812 & 0.0009 \\
\hline Cooperative $\tau_{0}$ and $\tau_{1}$ & -0.054 & 0.000 & 0.129 & 0.000 & 10.3 & -0.4813 & 0.0020 \\
\hline Non-cooperative $\tau_{0}$ and $\tau_{1}$ & -0.046 & -0.123 & -0.078 & 0.251 & 11.5 & -0.4808 & 0.0021 \\
\hline
\end{tabular}

Note: All $\tau_{0}, E\left(\tau_{1}\right)$, and crisis probabilities in the table are in percentage point terms. 
Figure 1: Optimal home and foreign capital taxes as a function of the size of the negative shock to the home country.
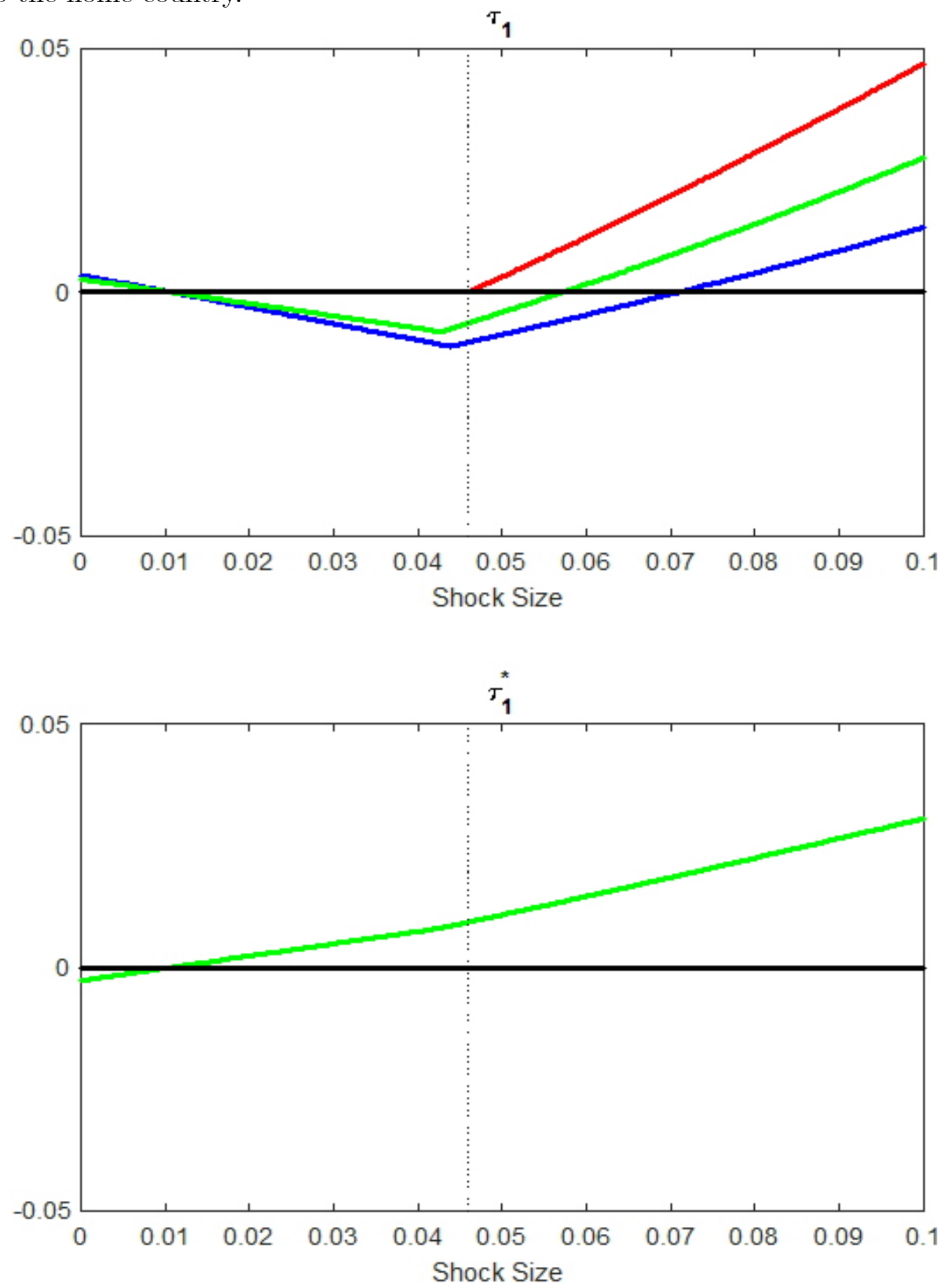

Notes: The blue line represents the scenario where the home country tax is set to maximize home country welfare, and the foreign tax is equal to zero. The green line represents the scenario where home and foreign tax rates are set non-cooperatively. The red line represents the cooperative scenario. The vertical dotted line marks the point where the home country borrowing constraint begins to bind in the no-tax scenario. 
Figure 2: Various home and foreign endogenous variables as a function of the size of the negative shock to the home country,
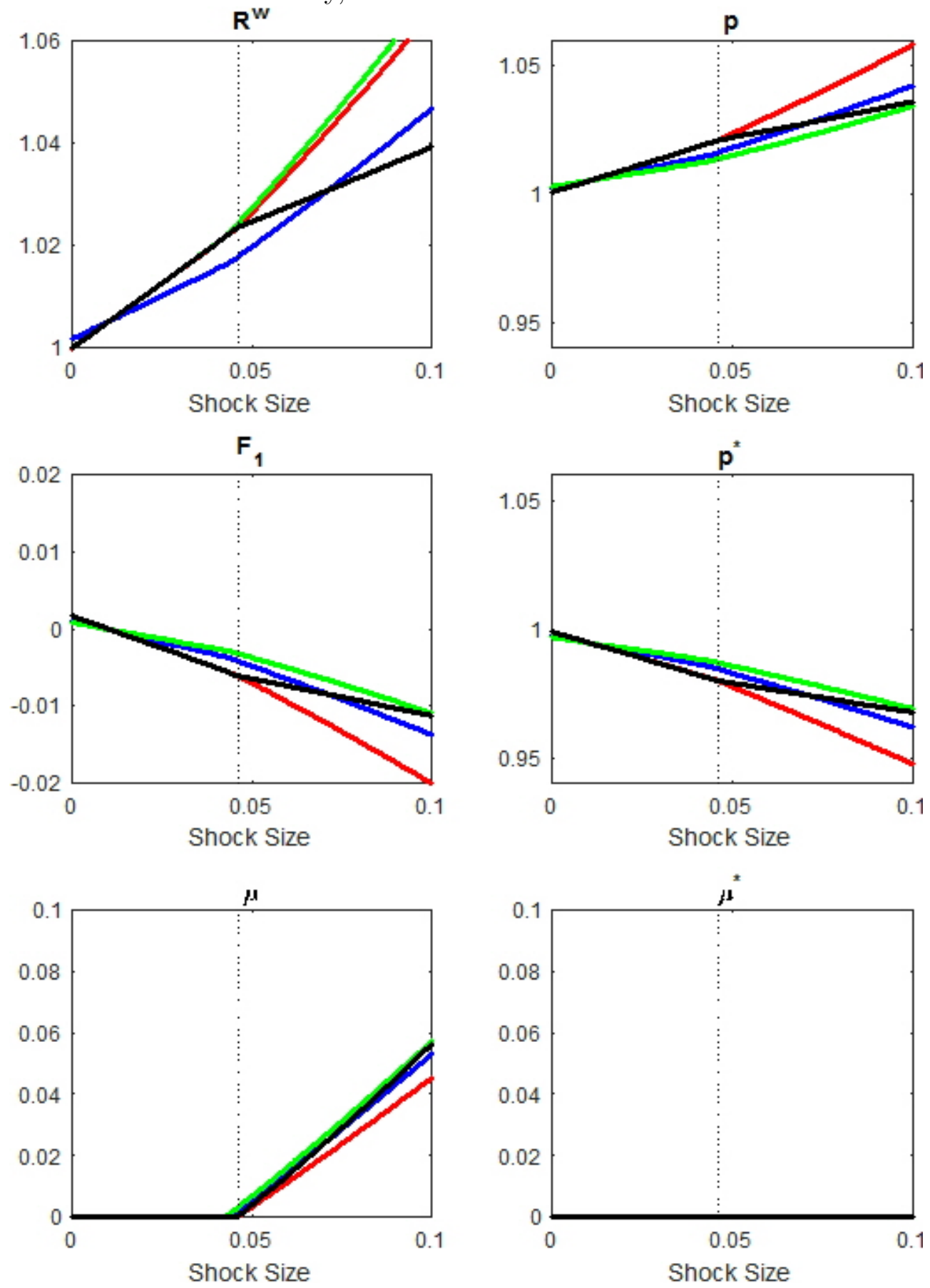

Notes: The black line represents the scenario where home and foreign taxes are equal to zero. The blue line represents the scenario where the home country tax is set to maximize home country welfare, and the foreign tax is equal to zero. The green line represents the scenario where home and foreign tax rates are set non-cooperatively. The red line represents the cooperative scenario. The vertical dotted line marks the point where the home country borrowing constraint begins to bind in the no-tax scenario. 
Figure 3: Home and foreign country welare as a function of the size of the negative shock to the home country,
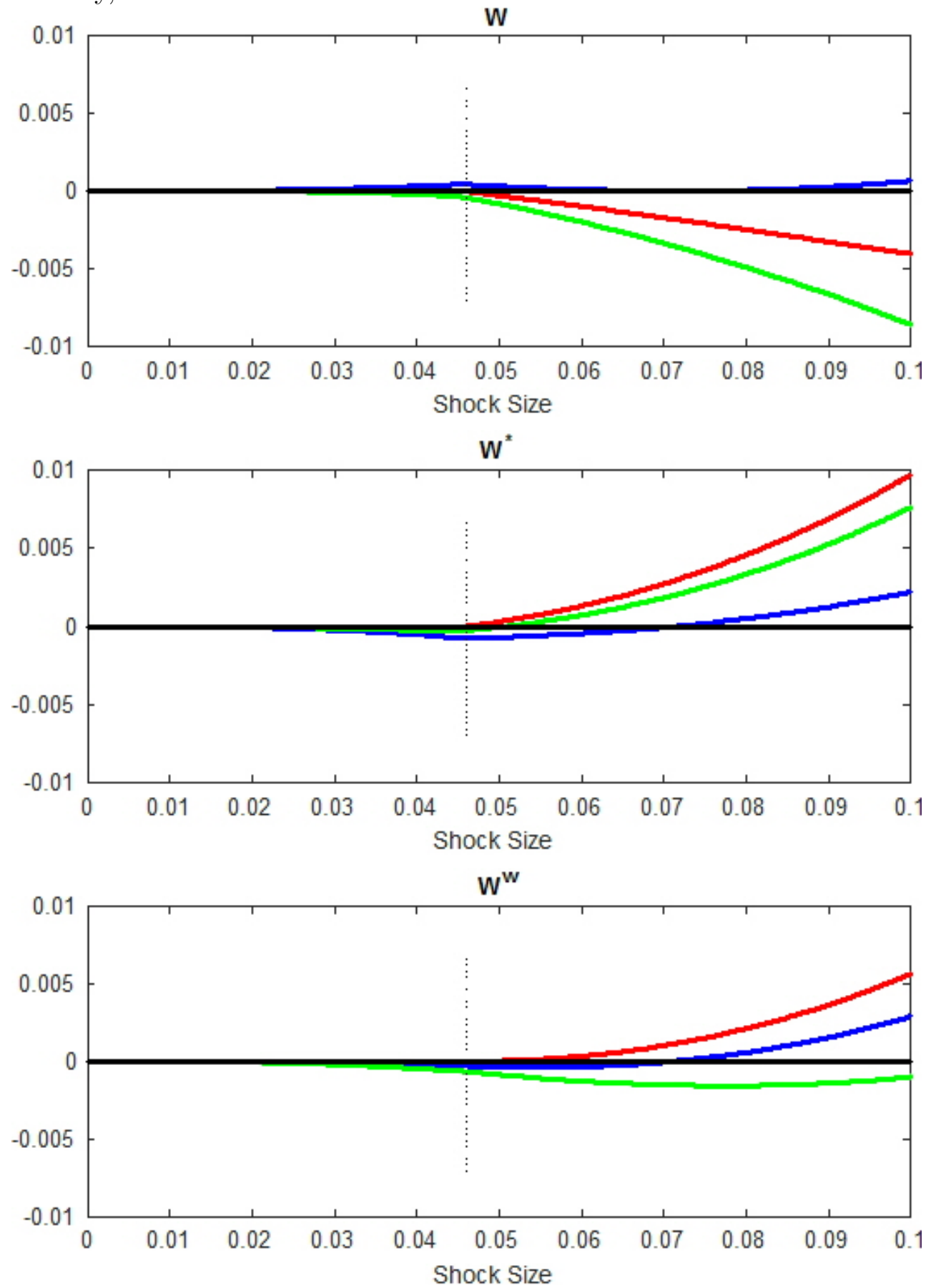

Notes: Graphs plot the difference in welfare from the no-tax regime. The blue line represents the case of unilateral home capital taxes. The green line represents non-cooperative home and foreign taxes, and the red line represents cooperative capital taxes. The vertical dotted line marks the point where the home country borrowing constraint begins to bind in the no-tax scenario. 
Figure 4: Home and foreign best responses following a negative shock in the home country.

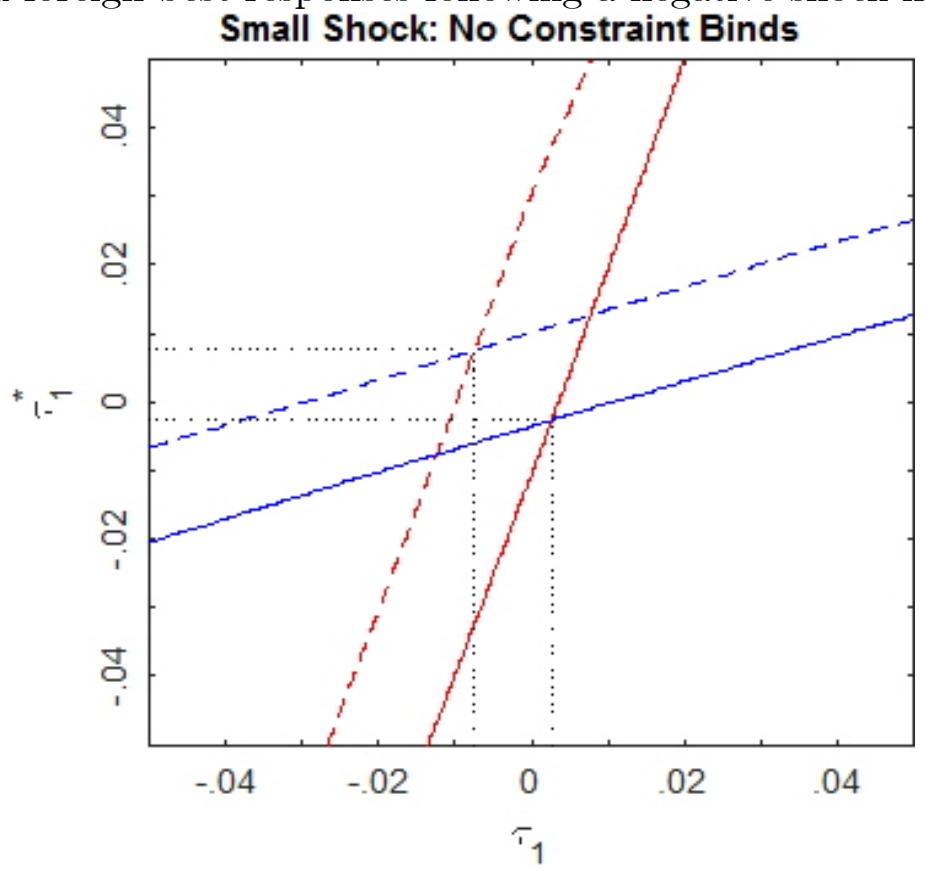

Larger Shock: Home Constraint Binds

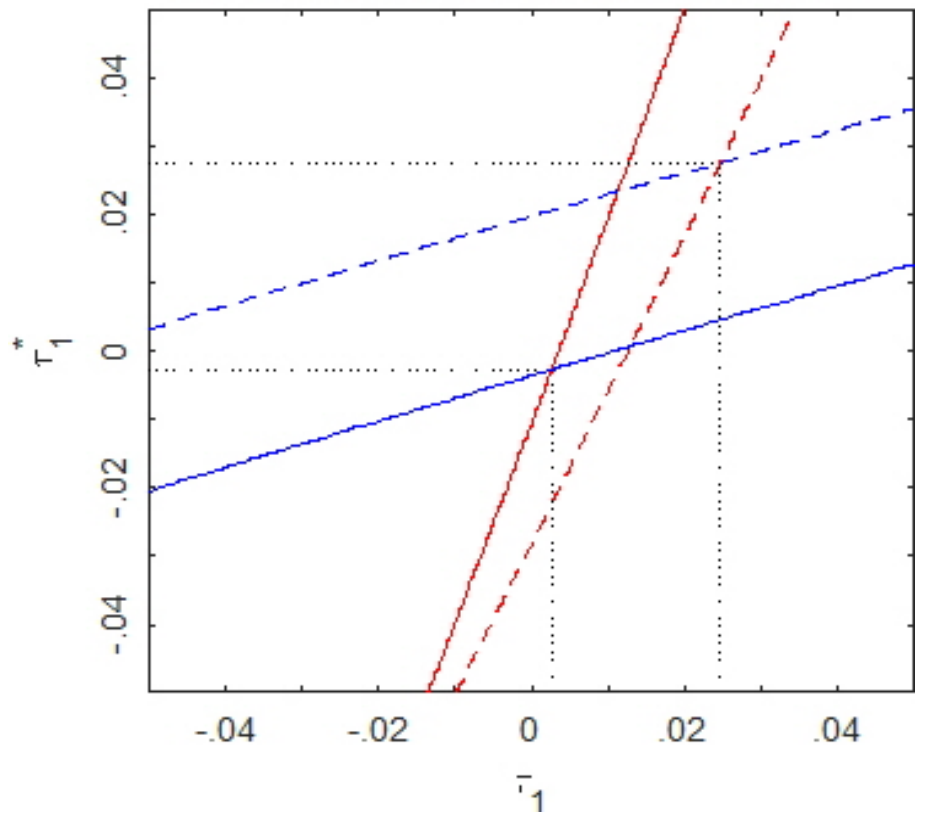

Notes: The red lines are the best responses of the home country tax to a given foreign country tax, and the blue lines are the best responses of the foreign country tax to a given home country tax. The solid best response lines are the pre-shock best responses, the dashed best response lines are the best responses after a negative shock to the home country. 
Figure 5: Home and foreign best responses following a negative shock in the home country. The shock size is calibrated so the figure zooms in on the region where the home constraint starts to bind.

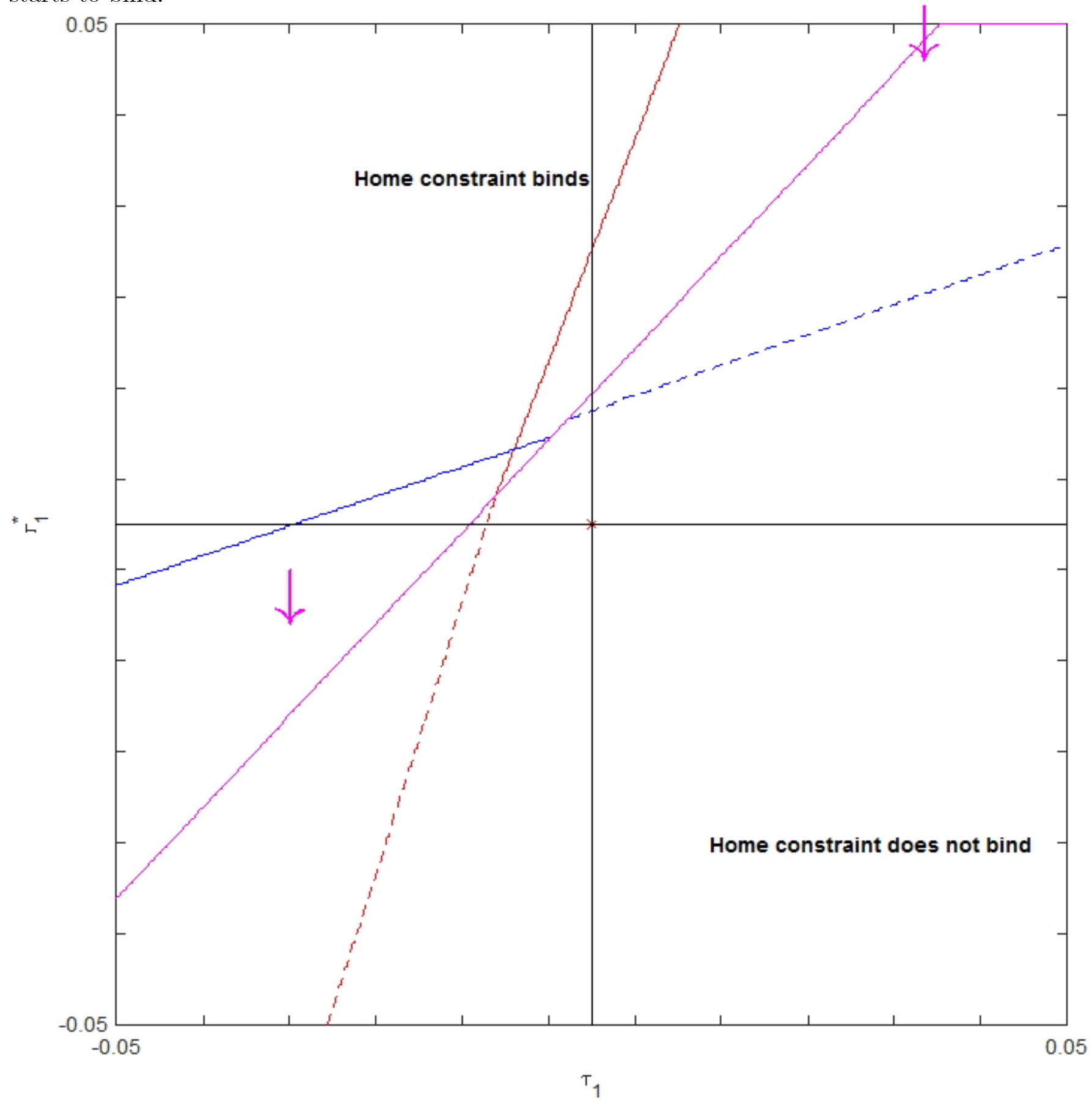

Notes: The red line is the best response of the home country tax to a given foreign country tax, and the blue line is the best response of the foreign country tax to a given home country tax. The purple diagonal line marks the frontier where above the purple line the home country borrowing constraint binds and below the frontier the borrowing constraint does not bind. 
Figure 6: Home and foreign best responses in period 0. Best responses are calculated assumin the post-shock policy regime is zero-tax.

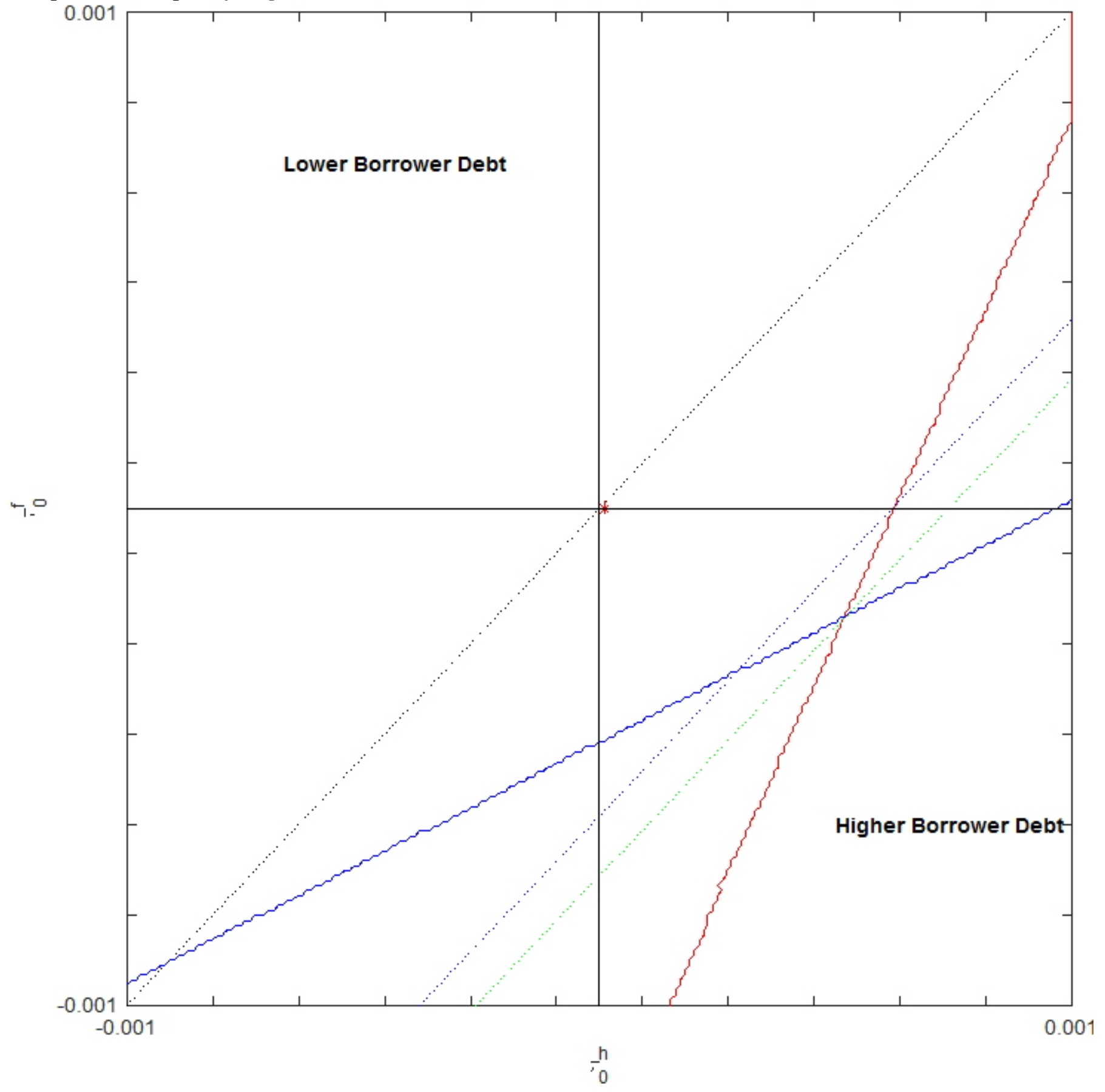

Notes: The red line is the best response of the home country tax to a given foreign country tax, and the blue line is the best response of the foreign country tax to a given home country tax. The black, blue, and green 45 degree lines are iso-debt lines, where the period 0 level of borrower debt is the same at each point along the line. Iso-debt lines to the right imply a higher level of period 0 borrower debt. 